\title{
Cavity Formation in Uranyl Ion Complexes with Kemp's Tricarboxylate: Grooved Diperiodic Nets and Polynuclear Cages
}

\author{
Pierre Thuéry*,† and Jack Harrowfield ${ }^{*,+}$ \\ ${ }^{\dagger}$ Université Paris-Saclay, CEA, CNRS, NIMBE, 91191 Gif-sur-Yvette, France \\ *Université de Strasbourg, ISIS, 8 allée Gaspard Monge, 67083 Strasbourg, France
}

\begin{abstract}
Kemp's triacid (cis,cis-1,3,5-trimethylcyclohexane-1,3,5-tricarboxylic acid, $\mathrm{H}_{3} \mathrm{kta}$ ) has been reacted with uranyl nitrate under solvo-hydrothermal conditions in the presence of diverse counterions or additional metal cations to give eight zero- or diperiodic complexes. All the coordination polymers in the series, $\left[\mathrm{PPh}_{3} \mathrm{Me}\right]\left[\mathrm{UO}_{2}(\mathrm{kta})\right] \cdot 0.5 \mathrm{H}_{2} \mathrm{O}(\mathbf{1}),\left[\mathrm{PPh}_{4}\right]\left[\mathrm{UO}_{2}(\mathrm{kta})\right](\mathbf{2}),\left[\mathrm{C}\left(\mathrm{NH}_{2}\right)_{3}\right]\left[\mathrm{UO}_{2}(\mathrm{kta})\right](\mathbf{3}),\left[\mathrm{Cd}(\text { bipy) })_{3}\right]\left[\mathrm{UO}_{2}(\mathrm{kta})\right]_{2}$ (4), and $\left[\mathrm{Zn}(\mathrm{phen})_{3}\right]\left[\mathrm{UO}_{2}(\mathrm{kta})\right]_{2} \cdot 2 \mathrm{H}_{2} \mathrm{O}(\mathbf{5})$ (bipy $=2,2^{\prime}$-bipyridine, phen $=1,10$-phenanthroline) crystallize as networks with the hcb topology, the ligand being in the chair conformation with the three carboxylate groups equatorial, except in $\mathbf{3}$ in which the axial/diequatorial boat conformation is present. Various degrees of corrugation and different arrangements of neighbouring layers are observed depending on the counterion, with complexes $\mathbf{4}$ and $\mathbf{5}$ in particular displaying cavities containing the bulky cations. $\left[\mathrm{Co}(\mathrm{en})_{3}\right]_{2}\left[\left(\mathrm{UO}_{2}\right)_{2}(\mathrm{kta})(\mathrm{Hkta})_{2}\right]_{2} \cdot 2 \mathrm{NMP} \cdot 10 \mathrm{H}_{2} \mathrm{O}(\mathbf{6})$ (en $=1$,2-ethanediamine) contains a metallatricyclic, tetranuclear anionic species, displaying two clefts in which the cations are held by extensive hydrogen bonding, and with the ligands in both triaxial chair and axial/diequatorial boat conformations. $\left[\left(\mathrm{UO}_{2}\right)_{3} \mathrm{~Pb}(\mathrm{kta})_{2}(\mathrm{Hkta})\left(\mathrm{H}_{2} \mathrm{O}\right)\right]_{2} \cdot 1.5 \mathrm{THF}(7)$ and $\left[\left(\mathrm{UO}_{2}\right)_{2} \mathrm{~Pb}_{2}(\mathrm{kta})_{2}(\mathrm{Hkta})(\mathrm{NMP})\right]_{2}(8)$ are two heterometallic cage compounds containing only the convergent, triaxial chair form of the ligand, which have the same topology in spite of the different $\mathrm{U} / \mathrm{Pb}$ ratio. These complexes are compared to previous ones also involving Kemp's triacid anions, and the roles of ligand conformation and of counterions in the formation of cavities, either in cage-like species or as grooves in diperiodic networks, is discussed.
\end{abstract}




\section{INTRODUCTION}

In recent years, several examples of uranyl-based cage-like species have been reported, the most remarkable by every measure being the series obtained with bridging peroxide anions ${ }^{1-5}$ and the very large, quasi-spherical assemblies containing $p$-carboxylatocalixarenes as ligands. ${ }^{6}$ Although carboxylate ligands are commonly used in the synthesis of uranyl ion complexes and in particular of coordination polymers and frameworks, ${ }^{7-11}$ they have given only about a dozen of cage-like polynuclear uranyl ion complexes, all of them of moderate size. ${ }^{12-22}$ Among the polycarboxylate ligands with an orientation of the coordinating groups suitable for the design of such species, the deprotonated forms of Kemp's triacid, cis,cis-1,3,5-trimethylcyclohexane1,3,5-tricarboxylic acid $\left(\mathrm{H}_{3} \mathrm{kta}\right)^{23}$ are particularly appealing and have produced octanuclear homometallic uranyl cages $^{15}$ and heterometallic uranyl-copper(II) dodeca- and hexadecanuclear species, ${ }^{16}$ as well as a uranyl-nickel(II) nanotubular assembly. ${ }^{15}$ This varied known coordination chemistry of Kemp's triacid and uranyl ion has already shown that the form of these complexes is highly sensitive to the nature of any associated cation, whether or not it is directly incorporated into the uranyl coordination oligomer or polymer, providing an incentive to further studies involving other counterions.

The conformational lability of Kemp's triacid has been exploited in areas ranging from molecular self-replication ${ }^{24}$ to basic studies of coordination chemistry. ${ }^{25-28}$ In the latter field it has even been found that the chair form of the central cyclohexane unit need not be retained, although known examples involve only two rather simple uranyl ion complexes. ${ }^{28,29}$ Non-chair conformations also appear to be rare in the crystal structures of purely organic species ${ }^{30,31}$ but the prospect that they might be a unique feature of uranyl ion complexes underlying novel structures was another reason which prompted us to further examine factors which could influence their occurrence. 
We report here the synthesis and crystal structure of eight uranyl ion complexes with Kemp's triacid anions, five of which involve anionic, diperiodic coordination polymers and three polynuclear, closed species, both groups providing an example of where the ligand adopts a non-chair conformation. The anionic coordination oligomers or polymers of uranyl ion and Kemp's triacid anions are associated with cations of rather varied characteristics. Three of these counterions are organic $\left(\mathrm{PPh}_{3} \mathrm{Me}^{+}, \mathrm{PPh}_{4}{ }^{+}, \mathrm{C}\left(\mathrm{NH}_{2}\right)_{3}{ }^{+}\right)$and the others are either an additional metal ion $\left(\mathrm{Pb}^{2+}\right)$ or metal ion complexes $\left(\left[\mathrm{Cd}(\text { bipy })_{3}\right]^{2+},\left[\mathrm{Zn}(\text { phen })_{3}\right]^{2+}\right.$ or $\left[\mathrm{Co}(\mathrm{en})_{3}\right]^{3+}$, with bipy $=2,2^{\prime}$-bipyridine, phen $=1,10$-phenanthroline, and en $=1,2$-ethanediamine) .

\section{EXPERIMENTAL SECTION}

Syntheses. Caution! Uranium is a radioactive and chemically toxic element, and uranium-containing samples must be handled with suitable care and protection.

$\left[\mathrm{UO}_{2}\left(\mathrm{NO}_{3}\right)_{2}\left(\mathrm{H}_{2} \mathrm{O}\right)_{2}\right] \cdot 4 \mathrm{H}_{2} \mathrm{O}$ (RP Normapur, 99\%) was purchased from Prolabo. Kemp's triacid was from Aldrich and $\left[\mathrm{Co}(\mathrm{en})_{3}\right] \mathrm{Cl}_{3} \cdot 3 \mathrm{H}_{2} \mathrm{O}$ was from Alfa-Aesar. Elemental analyses were performed by MEDAC Ltd. at Chobham, U.K. For all syntheses, the mixtures in demineralized water/organic solvent were placed in $10 \mathrm{~mL}$ tightly closed glass vessels and heated at $140{ }^{\circ} \mathrm{C}$ in a sand bath, under autogenous pressure.

$\left[P P h_{3} \mathrm{Me}\right]\left[\mathrm{UO}_{2}(\mathrm{kta})\right] \cdot 0.5 \mathrm{H}_{2} \mathrm{O}$ (1). $\mathrm{H}_{3} \mathrm{kta}(13 \mathrm{mg}, 0.05 \mathrm{mmol}),\left[\mathrm{UO}_{2}\left(\mathrm{NO}_{3}\right)_{2}\left(\mathrm{H}_{2} \mathrm{O}\right)_{2}\right] \cdot 4 \mathrm{H}_{2} \mathrm{O}$ (25 mg, $0.05 \mathrm{mmol})$, and $\mathrm{PPh} 3 \mathrm{MeBr}(18 \mathrm{mg}, 0.05 \mathrm{mmol})$ were dissolved in a mixture of water (0.6 mL) and DMF $(0.2 \mathrm{~mL})$. A few yellow crystals of complex 1 were obtained overnight. [PPh $]\left[\mathrm{UO}_{2}(\mathrm{kta})\right]$ (2). $\mathrm{H}_{3} \mathrm{kta}(13 \mathrm{mg}, 0.05 \mathrm{mmol}),\left[\mathrm{UO}_{2}\left(\mathrm{NO}_{3}\right)_{2}\left(\mathrm{H}_{2} \mathrm{O}\right)_{2}\right] \cdot 4 \mathrm{H}_{2} \mathrm{O}(25 \mathrm{mg}$, $0.05 \mathrm{mmol})$, and $\mathrm{PPh}_{4} \mathrm{Br}(21 \mathrm{mg}, 0.05 \mathrm{mmol})$ were dissolved in a mixture of water $(0.6 \mathrm{~mL})$ and NMP (0.2 mL). Yellow crystals of complex 2 were obtained overnight (13 mg, 30\% yield). Anal. Calcd for $\mathrm{C}_{36} \mathrm{H}_{35} \mathrm{O}_{8}$ PU: C, 50.01; H, 4.08. Found: C, 49.50; H, 4.25\%. 
$\left[\mathrm{C}\left(\mathrm{NH}_{2}\right)_{3}\right]\left[\mathrm{UO}_{2}(\mathrm{kta})\right](3) . \mathrm{H}_{3} \mathrm{kta}(13 \mathrm{mg}, 0.05 \mathrm{mmol}),\left[\mathrm{UO}_{2}\left(\mathrm{NO}_{3}\right)_{2}\left(\mathrm{H}_{2} \mathrm{O}\right)_{2}\right] \cdot 4 \mathrm{H}_{2} \mathrm{O}(25 \mathrm{mg}$, $0.05 \mathrm{mmol})$, and guanidinium nitrate $(24 \mathrm{mg}, 0.20 \mathrm{mmol})$ were dissolved in a mixture of water $(0.6 \mathrm{~mL})$ and THF $(0.2 \mathrm{~mL})$. Yellow crystals of complex 3 were obtained overnight $(9 \mathrm{mg}, 31 \%$ yield). Anal. Calcd for $\mathrm{C}_{13} \mathrm{H}_{21} \mathrm{~N}_{3} \mathrm{O}_{8} \mathrm{U}$ : C, 26.67; H, 3.62; N, 7.18. Found: $\mathrm{C}, 26.97 ; \mathrm{H}, 4.11 ; \mathrm{N}$, $7.04 \%$.

$\left[\mathrm{Cd}(\text { bipy })_{3}\right]\left[\mathrm{UO}_{2}(\mathrm{kta})\right]_{2}(4) . \mathrm{H}_{3} \mathrm{kta}(13 \mathrm{mg}, 0.05 \mathrm{mmol}),\left[\mathrm{UO}_{2}\left(\mathrm{NO}_{3}\right)_{2}\left(\mathrm{H}_{2} \mathrm{O}\right)_{2}\right] \cdot 4 \mathrm{H}_{2} \mathrm{O}(25$ $\mathrm{mg}, 0.05 \mathrm{mmol}), \mathrm{Cd}\left(\mathrm{NO}_{3}\right)_{2} \cdot 4 \mathrm{H}_{2} \mathrm{O}(16 \mathrm{mg}, 0.05 \mathrm{mmol})$ and 2,2'-bipyridine (24 mg, $\left.0.15 \mathrm{mmol}\right)$ were dissolved in a mixture of water $(0.6 \mathrm{~mL})$ and NMP $(0.2 \mathrm{~mL})$. Yellow crystals of complex 4 were obtained within one week (24 mg, 59\% yield). Anal. Calcd for $\mathrm{C}_{54} \mathrm{H}_{54} \mathrm{CdN}_{6} \mathrm{O}_{16} \mathrm{U}_{2}$ : $\mathrm{C}$, 39.75; H, 3.34; N, 5.15. Found: C, 39.70; H, 3.88; N, 5.12\%.

$\left[\mathrm{Zn}(\text { phen })_{3}\right]\left[\mathrm{UO}_{2}(\mathrm{kta})\right]_{2} \cdot 2 \mathrm{H}_{2} \mathrm{O}(5) \cdot \mathrm{H}_{3} \mathrm{kta}(13 \mathrm{mg}, 0.05 \mathrm{mmol}),\left[\mathrm{UO}_{2}\left(\mathrm{NO}_{3}\right)_{2}\left(\mathrm{H}_{2} \mathrm{O}\right)_{2}\right] \cdot 4 \mathrm{H}_{2} \mathrm{O}$ (25 mg, $0.05 \mathrm{mmol}), \mathrm{Zn}\left(\mathrm{NO}_{3}\right)_{2} \cdot 6 \mathrm{H}_{2} \mathrm{O}(15 \mathrm{mg}, 0.05 \mathrm{mmol})$ and 1,10-phenanthroline (28 mg, $0.16 \mathrm{mmol})$ were dissolved in a mixture of water $(0.6 \mathrm{~mL})$ and NMP $(0.2 \mathrm{~mL})$. Yellow crystals of complex 5 were obtained within three days (17 mg, 40\% yield). Elemental analysis results indicate the presence of about three water molecules in excess of those found from structure determination (see below). Anal. Calcd for $\mathrm{C}_{60} \mathrm{H}_{58} \mathrm{~N}_{6} \mathrm{O}_{18} \mathrm{U}_{2} \mathrm{Zn}+3 \mathrm{H}_{2} \mathrm{O}$ : C, 41.26; H, 3.69; N, 4.81. Found: C, 41.12; H, 4.11; N, 4.88\%.

$\left[\mathrm{Co}(\mathrm{en})_{3}\right]_{2}\left[\left(\mathrm{UO}_{2}\right)_{2}(\mathrm{kta})(\mathrm{Hkta})_{2}\right]_{2} \cdot 2 \mathrm{NMP} \cdot 1 \mathrm{OH}_{2} \mathrm{O} \quad$ (6). $\mathrm{H}_{3} \mathrm{kta} \quad(13 \mathrm{mg}, 0.05 \mathrm{mmol})$, $\left[\mathrm{UO}_{2}\left(\mathrm{NO}_{3}\right)_{2}\left(\mathrm{H}_{2} \mathrm{O}\right)_{2}\right] \cdot 4 \mathrm{H}_{2} \mathrm{O}(25 \mathrm{mg}, 0.05 \mathrm{mmol})$ and $\left[\mathrm{Co}(\mathrm{en})_{3}\right] \mathrm{Cl}_{3} \cdot 3 \mathrm{H}_{2} \mathrm{O}(24 \mathrm{mg}, 0.05 \mathrm{mmol})$ were dissolved in a mixture of water $(0.6 \mathrm{~mL})$ and NMP $(0.2 \mathrm{~mL})$. A few yellow crystals of complex 6 were obtained within three weeks.

$\left[\left(\mathrm{UO}_{2}\right)_{3} \mathrm{~Pb}(\mathrm{kta})_{2}(\mathrm{Hkta})\left(\mathrm{H}_{2} \mathrm{O}\right)\right]_{2} \cdot 1.5 \mathrm{THF} \quad$ (7). $\mathrm{H}_{3} \mathrm{kta} \quad(13 \mathrm{mg}, \quad 0.05 \quad \mathrm{mmol})$, $\left[\mathrm{UO}_{2}\left(\mathrm{NO}_{3}\right)_{2}\left(\mathrm{H}_{2} \mathrm{O}\right)_{2}\right] \cdot 4 \mathrm{H}_{2} \mathrm{O}(25 \mathrm{mg}, 0.05 \mathrm{mmol})$ and $\mathrm{Pb}\left(\mathrm{NO}_{3}\right)_{2}(17 \mathrm{mg}, 0.05 \mathrm{mmol})$, were dissolved in a mixture of water $(0.6 \mathrm{~mL})$ and THF $(0.2 \mathrm{~mL})$. A few yellow crystals of complex 7 were obtained within one week. 
$\left[\left(\mathrm{UO}_{2}\right)_{2} \mathrm{~Pb}_{2}(\mathrm{kta})_{2}(\mathrm{Hkta})(\mathrm{NMP})\right]_{2} \quad$ (8). $\mathrm{H}_{3} \mathrm{kta} \quad(13 \mathrm{mg}, \quad 0.05 \mathrm{mmol})$, $\left[\mathrm{UO}_{2}\left(\mathrm{NO}_{3}\right)_{2}\left(\mathrm{H}_{2} \mathrm{O}\right)_{2}\right] \cdot 4 \mathrm{H}_{2} \mathrm{O}(25 \mathrm{mg}, 0.05 \mathrm{mmol})$ and $\mathrm{Pb}\left(\mathrm{NO}_{3}\right)_{2}(33 \mathrm{mg}, 0.10 \mathrm{mmol})$, were dissolved in a mixture of water $(0.6 \mathrm{~mL})$ and NMP $(0.2 \mathrm{~mL})$. Yellow crystals of complex 8 were obtained in low yield within one week $(11 \mathrm{mg}, 36 \%$ yield based on the acid). Anal. Calcd for $\mathrm{C}_{82} \mathrm{H}_{110} \mathrm{~N}_{2} \mathrm{O}_{46} \mathrm{~Pb}_{4} \mathrm{U}_{4}$ : C, 27.05; H, 3.05; N, 0.77. Found: C, 27.36; H, 3.73; N, 0.86\%.

Crystallography. The data were collected at 100(2) K on a Bruker D8 Quest diffractometer equipped with an Incoatec Microfocus Source (I $\mu$ S 3.0 Mo) and a PHOTON III area detector, and operated through the APEX3 software. ${ }^{32}$ The crystals were mounted on Mitegen micromounts with a protective coating of Paratone-N oil (Hampton Research). The data were processed with SAINT, ${ }^{33}$ and absorption effects were corrected empirically with SADABS. ${ }^{34,35}$ All structures were solved by intrinsic phasing with SHELXT, ${ }^{36}$ expanded by subsequent difference Fourier synthesis and refined by full-matrix least-squares on $F^{2}$ with SHELXL, ${ }^{37}$ using the ShelXle interface. ${ }^{38}$ All non-hydrogen atoms were refined with anisotropic displacement parameters. The carbon-bound hydrogen atoms were introduced at calculated positions and treated as riding atoms with an isotropic displacement parameter equal to 1.2 times that of the parent atom ( 1.5 for $\mathrm{CH}_{3}$, with optimized geometry). Details concerning the hydrogen atoms bound to oxygen or nitrogen atoms are given below. Crystal data and structure refinement parameters are given in Table 1 . The molecular plots were drawn with ORTEP-3, ${ }^{39}$ and the polyhedral representations with VESTA. ${ }^{40}$ The topological analyses and nodal representations were made with ToposPro. ${ }^{41}$ Special details are as follows.

Complex 1. The water molecule (O9) was given an occupancy factor of 0.5 in order to retain an acceptable displacement parameter. Its hydrogen atoms were found and they were treated as riding atoms.

Complex 2. The refined Flack parameter was 0.006(5). 
Complex 3. The hydrogen atoms bound to nitrogen atoms were introduced at calculated positions and were treated as riding atoms. The structure was refined as a 2-component inversion twin with a Flack parameter value of 0.493(11).

Complex 5. The hydrogen atoms of only one water molecule have been found, and they were treated as riding atoms. The software SQUEEZE ${ }^{42}$ has been used to take into account the contribution of other, badly resolved water molecules present (solvent accessible volume of $3085 \AA^{3}$ per unit cell, 741 electrons found, corresponding to 4 or 5 extra water molecules per formula unit). This is in rough agreement with the three additional water molecules found from elemental analysis (see above).

Complex 6. The NMP molecule is disordered over two positions sharing the oxygen atom, which were refined with occupancy parameters constrained to sum to unity and restraints on bond lengths and displacement parameters. The hydrogen atoms bound to nitrogen atoms were introduced at calculated positions, and those bound to oxygen atoms were found, except for those of one water molecule, and they were refined with restraints on bond lengths and angles and an isotropic displacement parameter equal to $1.2(\mathrm{OH})$ or $1.5\left(\mathrm{H}_{2} \mathrm{O}\right)$ that of the attached oxygen atom.

Complex 7. The crystals were of very low quality and the results are based on the best data collection out of the five which were made on different crystals. One of the uranium atoms (U6) and the two lead atoms are disordered over two positions (one of them largely dominant) which have been refined with occupancy parameters constrained to sum to unity. Considering the low occupancy of position U6B (0.08), it is unsurprising that the associated disorder on the oxo atoms and coordinated carboxylate groups is unresolved. Large residual electron density peaks located near the other uranium atoms possibly indicate further disorder. These peaks are present whatever the absorption correction method used (multi-scan or numerical based on $\mu$ calculated or deduced from formula). One of the THF molecules was given an occupancy 
parameter of 0.5 in order to retain acceptable displacement parameters. The hydrogen atoms of the two carboxylic acid groups and the two water molecules were not found. Although voids are present, the SQUEEZE software does not significantly improve the results.

Complex 8. The crystals were of poor quality and the results are based on the best data collection out of the four which were made on different crystals. Atom $\mathrm{Pb} 2$ was considered to be disordered over two positions which were refined with occupancy parameters constrained to sum to unity. One of them $(\mathrm{Pb} 2 \mathrm{~A})$ is however largely dominant $[0.860(2)]$. The second $(\mathrm{Pb} 2 \mathrm{~B})$ is not compatible with the carboxylate oxygen atom O12. The latter is thus necessarily disordered also but, although its displacement ellipsoid is much elongated, the disorder could not be resolved, which may not be too surprising considering the low expected occupancy of the minor component $(0.14)$. The hydrogen atoms of the carboxylic acid groups were not found.

Table 1. Crystal Data and Structure Refinement Details

\begin{tabular}{|c|c|c|c|c|c|c|c|c|}
\hline & 1 & 2 & 3 & 4 & 5 & 6 & 7 & 8 \\
\hline chemical formula & $\mathrm{C}_{31} \mathrm{H}_{34} \mathrm{O}_{8.5} \mathrm{PU}$ & $\mathrm{C}_{36} \mathrm{H}_{35} \mathrm{O}_{8} \mathrm{PU}$ & $\mathrm{C}_{13} \mathrm{H}_{21} \mathrm{~N}_{3} \mathrm{O}_{8} \mathrm{U}$ & $\mathrm{C}_{54} \mathrm{H}_{54} \mathrm{CdN}_{6} \mathrm{O}_{16} \mathrm{U}_{2}$ & $\mathrm{C}_{60} \mathrm{H}_{58} \mathrm{~N}_{6} \mathrm{O}_{18} \mathrm{U}_{2} \mathrm{Zn}$ & $\mathrm{C}_{94} \mathrm{H}_{180} \mathrm{Co}_{2} \mathrm{~N}_{14} \mathrm{O}_{56} \mathrm{U}_{4}$ & $\mathrm{C}_{78} \mathrm{H}_{108} \mathrm{O}_{51.5} \mathrm{~Pb}_{2} \mathrm{U}_{6}$ & $\mathrm{C}_{82} \mathrm{H}_{110} \mathrm{~N}_{2} \mathrm{O}_{46} \mathrm{~Pb}_{4} \mathrm{U}_{4}$ \\
\hline$M\left(\mathrm{~g} \mathrm{~mol}^{-1}\right)$ & 811.58 & 864.64 & 585.36 & 1631.49 & 1692.55 & 3472.49 & 3712.20 & 3640.59 \\
\hline $\begin{array}{l}\text { cryst syst } \\
\text { space group }\end{array}$ & $\begin{array}{l}\text { orthorhombic } \\
\text { Pbca }\end{array}$ & $\begin{array}{l}\text { monoclinic } \\
P 2_{1}\end{array}$ & $\begin{array}{l}\text { orthorhombic } \\
P 2,2,2\end{array}$ & $\begin{array}{l}\text { orthorhombic } \\
P b c n\end{array}$ & $\begin{array}{l}\text { orthorhombic } \\
P b c a\end{array}$ & $\begin{array}{l}\text { triclinic } \\
P_{\overline{1}}\end{array}$ & $\begin{array}{l}\text { orthorhombic } \\
P b c n\end{array}$ & monoclinic \\
\hline & $18.4734(12)$ & $9.8830(3)$ & $\begin{array}{l}9.6146(4) \\
9.6121\end{array}$ & $19.4956(6)$ & $28.4720(8)$ & $\begin{array}{l}P \overline{1} \\
14.2652(4)\end{array}$ & $\begin{array}{l}P b c n \\
55.140(2)\end{array}$ & $\begin{array}{l}C 2 / c \\
249526(9)\end{array}$ \\
\hline $\begin{array}{l}a(\AA) \\
b(\AA)\end{array}$ & $16.8473(10)$ & $14.5207(5)$ & $9.6594(3)$ & $16.1938(5)$ & $25.8269(8)$ & $\begin{array}{l}14.2652(4) \\
15.0547(5)\end{array}$ & $\begin{array}{l}55.140(2) \\
15.0492(6)\end{array}$ & $\begin{array}{l}24.9526(9) \\
17.2040(6)\end{array}$ \\
\hline$c(\AA)$ & $19.5280(14)$ & $11.5287(4)$ & $19.0425(7)$ & $16.4024(5)$ & $35.2019(11)$ & $16.0721(5)$ & $\begin{array}{l}15.0492(6) \\
27.2341(10)\end{array}$ & $\begin{array}{l}17.2040(6) \\
23.1949(8)\end{array}$ \\
\hline$\alpha(\operatorname{deg})$ & 90 & 90 & 90 & 90 & 90 & $97.9413(13)$ & & $23.1949(8)$ \\
\hline$\beta(\mathrm{deg})$ & & $101.9675(17)$ & & & & & 90 & 90 \\
\hline & & & & & & $115.1356(13)$ & 90 & $97.5558(13)$ \\
\hline$\gamma(\operatorname{deg})$ & 90 & 90 & 90 & 90 & 90 & $99.4142(13)$ & 90 & 90 \\
\hline$V\left(\AA^{3}\right)$ & $6077.6(7)$ & $1618.50(9)$ & $1768.50(11)$ & $5178.4(3)$ & $25885.5(14)$ & $3052.33(17)$ & $22599.2(15)$ & $9870.8(6)$ \\
\hline$Z$ & 8 & 2 & 4 & 4 & 16 & 1 & 8 & 4 \\
\hline reflns colled & 153552 & 209309 & 167597 & 217445 & 415805 & 33213 & 232246 & 31580 \\
\hline indep reflns & 5775 & 8370 & 4557 & 4911 & 24562 & 11526 & 21242 & 9377 \\
\hline obsd reflns $[I>2 \sigma(I)]$ & 5144 & 7939 & 4442 & 4459 & 19883 & 10249 & 15691 & 8452 \\
\hline$R_{\text {int }}$ & 0.057 & 0.092 & 0.066 & 0.069 & 0.104 & 0.032 & 0.189 & 0.047 \\
\hline params refined & 383 & 419 & 230 & 360 & 1579 & 860 & 1309 & 642 \\
\hline$R_{1}$ & 0.019 & 0.022 & 0.018 & 0.029 & 0.034 & 0.037 & 0.065 & 0.060 \\
\hline$w R_{2}$ & 0.045 & 0.043 & 0.041 & 0.078 & 0.078 & 0.085 & 0.136 & 0.128 \\
\hline$S$ & 1.035 & 1.076 & 1.066 & 1.041 & 1.019 & 1.065 & 1.055 & 1.329 \\
\hline$\Delta \rho_{\min }\left(\mathrm{e} \AA^{-3}\right)$ & -0.95 & -1.26 & -1.03 & -3.10 & -2.63 & -2.14 & -2.66 & -2.66 \\
\hline$\Delta \rho_{\max }\left(\mathrm{e} \AA^{-3}\right)$ & 2.00 & 1.27 & 1.91 & 1.41 & 1.91 & 3.18 & 6.76 & 4.10 \\
\hline $\begin{array}{l}\text { CCDC deposition } \\
\text { number }\end{array}$ & 2037808 & 2037809 & 2037810 & 2037811 & 2037812 & 2037813 & 2037814 & 2037815 \\
\hline
\end{tabular}

\section{RESULTS AND DISCUSSION}

Synthesis. All complexes 1-8 were obtained in crystalline form under solvohydrothermal conditions at a temperature of $140{ }^{\circ} \mathrm{C}$, and the crystals were deposited directly from the pressurized and heated reaction mixtures and not as a result of subsequent cooling (as 
determined from visual inspection of the transparent vials). The use of acetonitrile as organic cosolvent generally results in isolation of the complex $\left[\mathrm{UO}_{2}(\mathrm{Hkta})\right] \cdot \mathrm{CH}_{3} \mathrm{CN},{ }^{15}$ whatever the counterions or additional species present, and this solvent has thus been avoided. Most complexes were obtained with $N$-methyl-2-pyrrolidone (NMP) as a cosolvent $(\mathbf{2}, \mathbf{4 - 6}$ and $\mathbf{8})$, with only 1 being crystallized with $N, N$-dimethylformamide (DMF), and 3 and 7 with tetrahydrofuran (THF). It is notable however that the complex $\left[\mathrm{H}_{2} \mathrm{NMe}_{2}\right]\left[\mathrm{UO}_{2}(\mathrm{kta})\right]$, previously described, ${ }^{29}$ was obtained in syntheses with $\mathrm{DMF}$ and $\mathrm{PPh}_{4}{ }^{+}$or $\mathrm{C}\left(\mathrm{NH}_{2}\right)_{3}{ }^{+}$as deliberately added possible counterions, highlighting the subtlety of factors which influence the solubility of such materials. NMP and THF are retained as solvents in the crystals of 6 and 7 only, while NMP is an additional ligand in $\mathbf{8}$. In no case are hydrolysis products present, in the form of either oxoor hydroxo-bridged uranyl oligomers, or species resulting from degradation of the organic cosolvent. Even in the cases in which it is absent from the final compound, the organic cosolvent exerts an influence through increasing the solubility of the species present and possibly changing the acidity of the solution. The uranyl/ligand stoichiometry was $1: 1$ in all the syntheses, compatible with the formation of an anionic species and thus incorporation of structure-directing counterions. This stoichiometry is retained in the crystalline complexes in most cases, the only exceptions being for complexes $\mathbf{6}$ and $\mathbf{8}$, in which it is 2:3.

Crystal Structures. Two compounds containing phosphonium counterions were obtained, $\left[\mathrm{PPh}_{3} \mathrm{Me}\right]\left[\mathrm{UO}_{2}(\mathrm{kta})\right] \cdot 0.5 \mathrm{H}_{2} \mathrm{O}(\mathbf{1})$ and $\left[\mathrm{PPh}_{4}\right]\left[\mathrm{UO}_{2}(\mathrm{kta})\right](2)$. In both of them, the unique uranyl cation is chelated in the $\kappa^{2} O, O^{\prime}$ mode by three carboxylate groups and the uranium atom is thus in a hexagonal bipyramidal environment [U-O(oxo), 1.766(2)-1.779(4) $\AA$; U-O(carboxylato), 2.400(4)-2.545(3) A, including both compounds] (Figures 1 and 2). The 


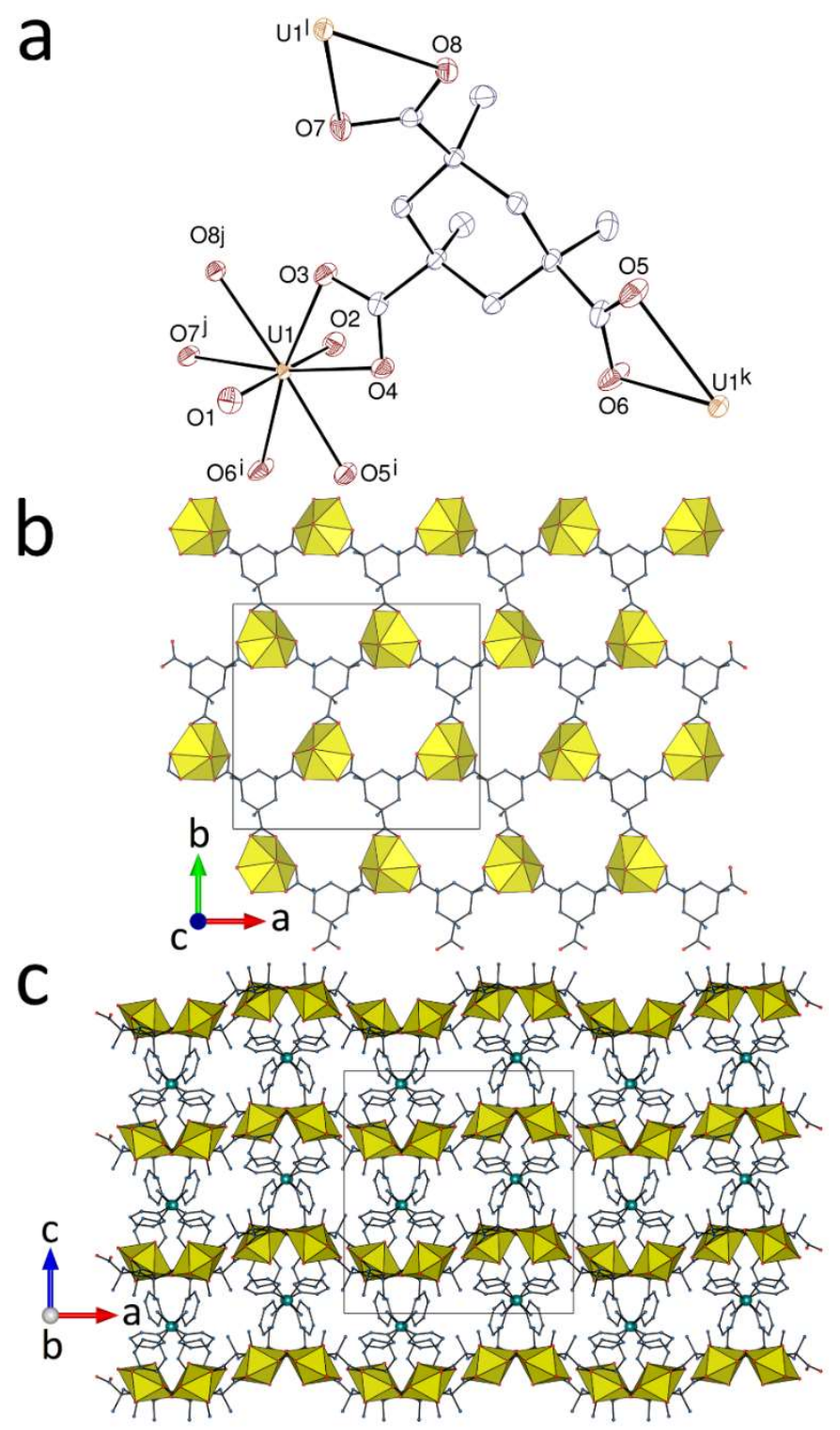

Figure 1. (a) View of compound 1. Displacement ellipsoids are drawn at the 50\% probability level. The counterion, solvent molecules and hydrogen atoms are omitted. Symmetry codes: $\mathrm{i}=1-x, y-1 / 2,3 / 2-z ; \mathrm{j}=1 / 2-x, y-1 / 2$, $z ; \mathrm{k}=1-x, y+1 / 2,3 / 2-z ; 1=1 / 2-x, y+1 / 2, z$. (b) View of the diperiodic assembly. (c) Packing with layers viewed edge-on. Hydrogen atoms and solvent molecules are omitted. Uranium coordination polyhedra are colored yellow and phosphorus atoms are shown as blue spheres. 


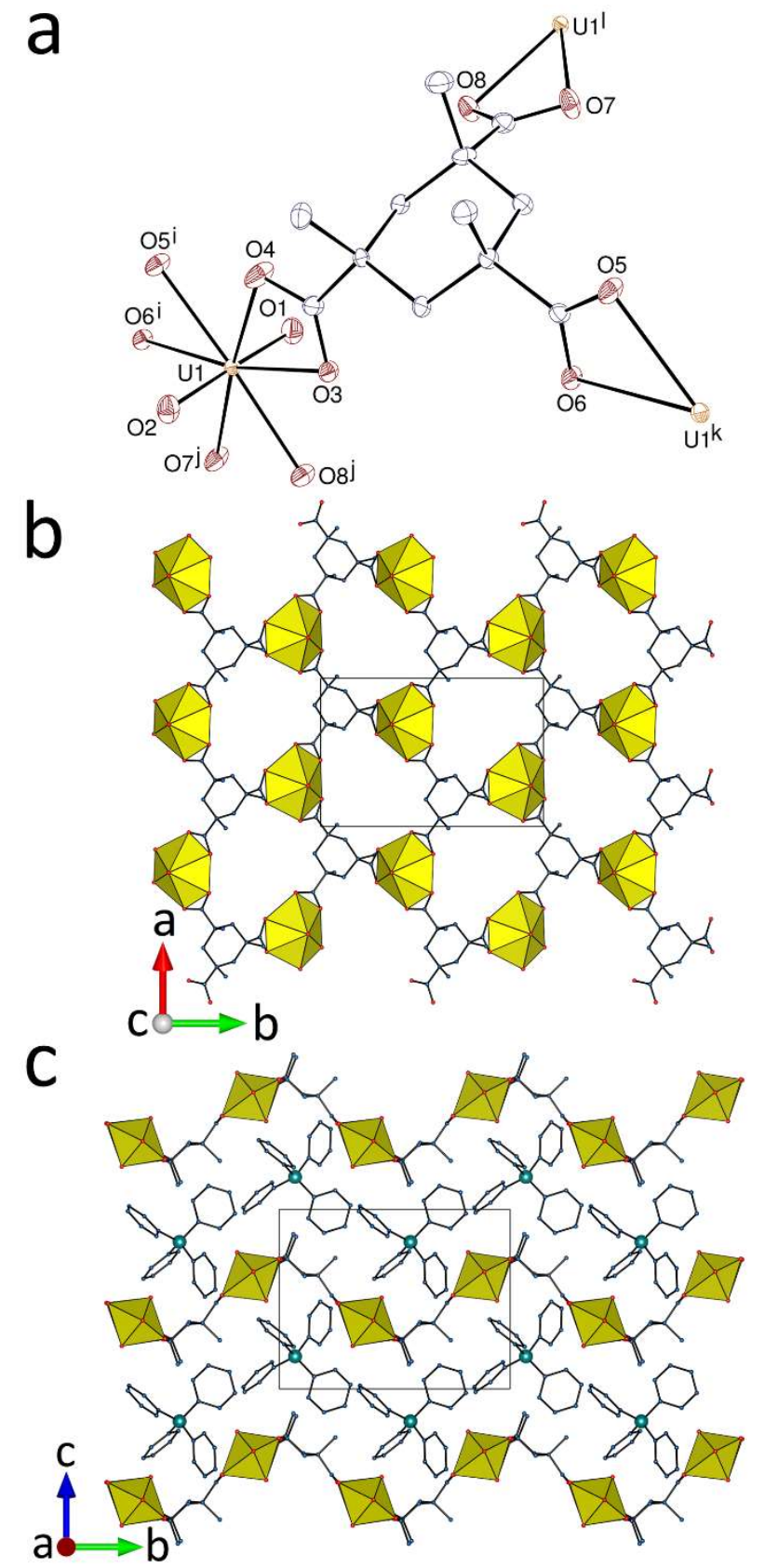

Figure 2. (a) View of compound 2. Displacement ellipsoids are drawn at the $50 \%$ probability level. The counterion and hydrogen atoms are omitted. Symmetry codes: $\mathrm{i}=x+1, y, z ; \mathrm{j}=1-x, y-1 / 2,1-z ; \mathrm{k}=x-1, y, z ; 1=1-x$, $y+1 / 2,1-z$. (b) View of the diperiodic assembly. (c) Packing with layers viewed edge-on. Uranium coordination polyhedra are colored yellow and phosphorus atoms are shown as blue spheres.

$\mathrm{kta}^{3-}$ ligand is in the chair conformation with the three carboxylate groups equatorial (a form denoted eee), as found in other uranyl ion complexes. ${ }^{15,16}$ Kemp's triacid is most often found in the chair conformation with the three carboxylic groups axial (aaa), in keeping with the 
methyl groups being associated with larger 1,3-diaxial repulsions, but the added electrostatic repulsion in the tris-deprotonated form favors the eee conformation. ${ }^{23,43}$ This equilibrium is easily disturbed in Kemp's acid derivatives ${ }^{44}$ as well as in metal complexes. ${ }^{45}$ The ligand conformations and carboxylate coordination modes in the complexes of the present series are shown in Scheme 1. In complexes $\mathbf{1}$ and $\mathbf{2}$, the divergently bonded, discoidal-shaped eee

\section{Scheme 1. Conformations and Coordination Modes of kta ${ }^{3-} / \mathrm{Hkta}^{2-}$ in Complexes 1-8}
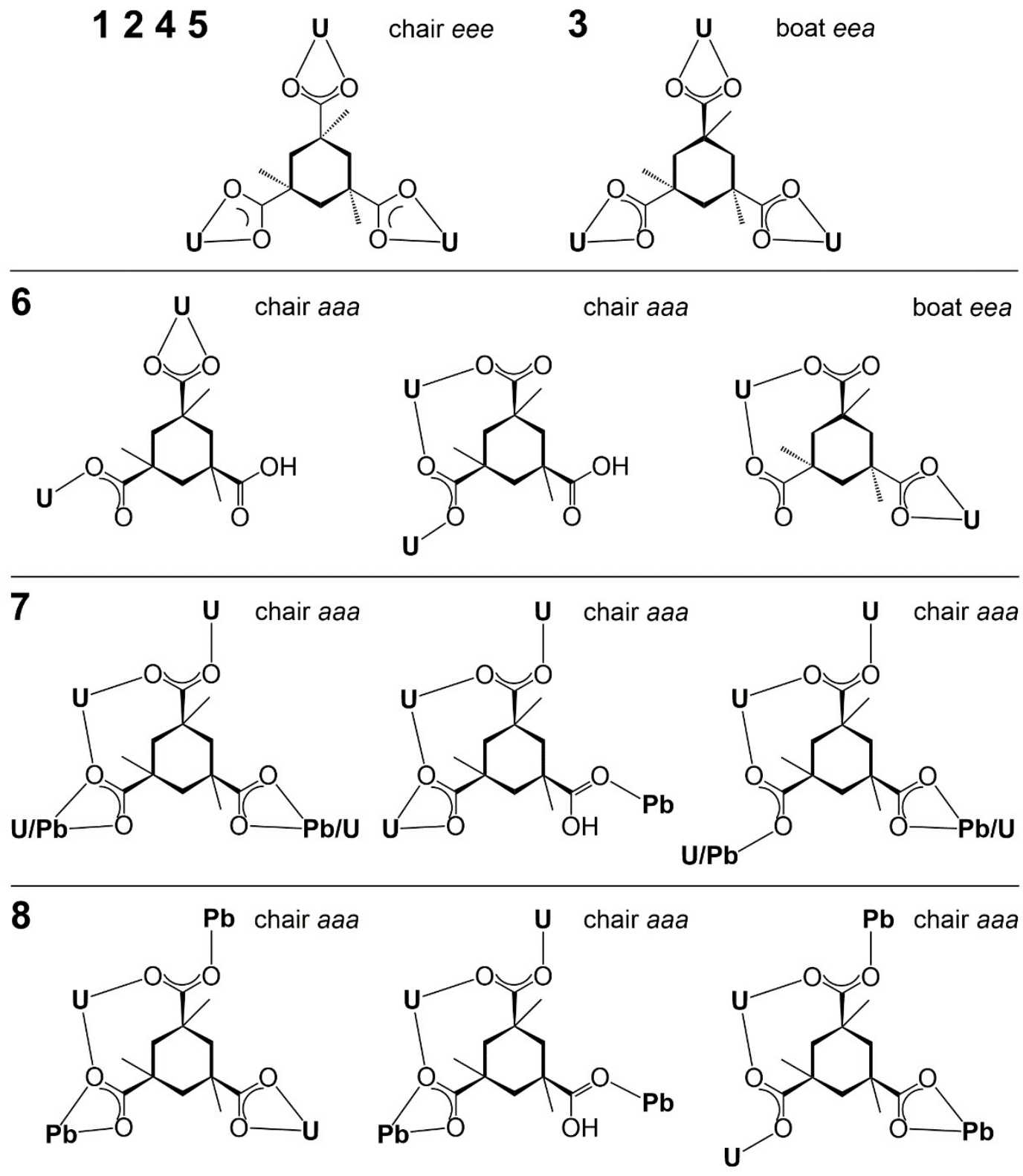
geometry favors formation of diperiodic coordination polymers, parallel to (001) in both, in which both metal and ligand are 3 -coordinated (3-c) nodes, and having the $6^{3}$ vertex symbol and the honeycomb (hcb) topology. The carboxylates are tilted slightly away from the mean ring plane, so that adoption of a diperiodic form close to planar involves alternation of the ligand tripod orientation towards the mean plane of the polymer sheet (Figures 1c and 2c). Exchange of tetrahedral $\mathrm{PPh}_{4}{ }^{+}$for trigonal $\mathrm{PPh}_{3} \mathrm{Me}^{+}$as a counterion to anionic uranyl ion complexes often has only relatively subtle consequences, but there are cases in which it substantially modifies the nature of the isolated, crystalline species. ${ }^{46}$ The difference here is obvious when the diperiodic networks are seen edge-on (Figures 1c and 2c). While the layers in 1 are gently undulating, those in $\mathbf{2}$ are sawtooth-shaped when viewed down [100], the largest dihedral angle between the equatorial planes of successive uranyl groups along [100] in $\mathbf{1}$ being $52.78(3)^{\circ}$ and that between adjacent groups along [010] in 2 being $64.25(6)^{\circ}$. This makes the layers slightly thicker in $\mathbf{2}$, with a distance between the extreme mean planes defined by protruding methyl groups of $\sim 8.2 \AA$, against $\sim 7.5 \AA$ in $\mathbf{1}$. The $\mathrm{PPh}_{4}{ }^{+}$cations in 2 , as well as less obviously the $\mathrm{PPh}_{3} \mathrm{Me}^{+}$cations in $\mathbf{1}$, are partly embedded in the grooves, thus suggesting that their structuredirecting effect could be through inducing the sheets to partly wrap around them. The sheets lie next to one another in a bump-to-hollow fashion, with the cations sandwiched in between. Separations of the mean planes of the sheets are $9.76 \AA(=c / 2)$ in $\mathbf{1}$, and $11.53 \AA(=c)$ in $\mathbf{2}$, reflecting the differences in size and form of the cations. The shortest P...P separations are $8.4255(5) \AA$ in 1 and $9.2595(16) \AA$ in 2 , and no distance between aromatic ring centroids is shorter than $5 \AA$, which is indicative of the absence of $\pi$-stacking and strong "phenyl embrace" interactions, ${ }^{47}$ and thus of the possible presence of stronger interactions involving the layers, these being mainly coulombic but involving also weaker components. Examination of the Hirshfeld surfaces $(\mathrm{HSs})^{48}$ of both cations calculated with CrystalExplorer (Ver. 3.1) ${ }^{49}$ indicates that they are involved in multiple $\mathrm{CH} \cdots \mathrm{O}$ hydrogen bonds ${ }^{50,51}$ (and some $\mathrm{CH} \cdots \pi$ interactions), 
the methyl group of $\mathrm{PPh}_{3} \mathrm{Me}^{+}$in $\mathbf{1}$ being one of the centres involved explaining the lesser intersheet distance in the structure of this complex. The Kitaigorodski packing index (KPI, calculated with PLATON ${ }^{52}$ ) is 0.67 for $\mathbf{1}$ (with disordered solvent excluded) and 0.69 for $\mathbf{2}$, indicating that no significant free space is present.

A different situation occurs with the guanidinium cation, smaller than the phosphoniums but remarkable for its hydrogen bonding possibilities, in the complex $\left[\mathrm{C}\left(\mathrm{NH}_{2}\right)_{3}\right]\left[\mathrm{UO}_{2}(\mathrm{kta})\right](3)$. Here also, the unique uranyl cation is tris-chelated by three carboxylate groups [U-O(oxo), 1.761(4) and 1.790(3) $\AA$; U-O(carboxylato), 2.421(4)-2.464(4) $\AA]$ so that both metal and ligand are 3-c nodes in the diperiodic hcb network formed, parallel to (001) (Figure 3). Instead of having the usual chair conformation, the $\mathrm{kta}^{3-}$ ligand adopts the boat geometry, with two carboxylate groups equatorial and one $(\mathrm{O} 5, \mathrm{O} 6)$ axial (eea). This conformation has previously been observed in two isomorphous uranyl complexes, $\left[\mathrm{H}_{2} \mathrm{NMe}_{2}\right]\left[\mathrm{UO}_{2}(\mathrm{kta})\right]{ }^{29}$ and $\left[\mathrm{UO}_{2} \mathrm{Cs}(\mathrm{kta})\right],{ }^{28}$ which also form hcb networks. Apart from these two cases, there are only two occurrences of twist-boat conformations, both in organic compounds and also involving the trianionic form of Kemp's triacid. ${ }^{30,31}$ Due to this conformational change, the layers in $\mathbf{3}$ are much more deeply furrowed than in $\mathbf{1}$ or $\mathbf{2}$, the equatorial planes of successive uranyl ions along [100] making a dihedral angle of $110.22(5)^{\circ}$, and, at $\sim 9 \AA$, the thickness of the layers, measured between the mean planes of outermost methyl groups, is larger than in $\mathbf{1}$ and $\mathbf{2}$. In contrast to those in $\mathbf{1}$ and $\mathbf{2}$, the layers in $\mathbf{3}$ stack together in a bump-to-bump, hollow-to-hollow manner, with a slight shift absent in the structure of $\left[\mathrm{H}_{2} \mathrm{NMe}_{2}\right]\left[\mathrm{UO}_{2}(\mathrm{kta})\right]$ but found also in that of $\left[\mathrm{UO}_{2} \mathrm{Cs}(\mathrm{kta})\right]$. A similar arrangement also occurs between the corrugated layers in $[\mathrm{Hbipy}]\left[\mathrm{UO}_{2}(\mathrm{kta})\right] \cdot 0.5 \mathrm{H}_{2} \mathrm{O} \cdot 0.25 \mathrm{THF} .{ }^{16}$ In all of these cases, the grooves of adjacent layers associate to form channels, occupied here by the protruding methyl groups, leaving no free space (KPI, 0.68). The guanidinium cations are completely embedded within the polymer sheets, with all six ammonium hydrogen atoms involved in hydrogen bonding to carboxylate 
or uranyl oxo groups $\left[\mathrm{N} \cdots \mathrm{O}, 2.893(7)-3.398(7) \AA ; \mathrm{N}-\mathrm{H} \cdots \mathrm{O}, 139-166^{\circ}\right]$. In two cases, with atoms $\mathrm{O} 1$ and $\mathrm{O} 5$ as acceptors, guanidinium acts as a chelate with formation of rings with the graph set descriptor ${ }^{53,54} R_{2}{ }^{1}(6)$. The strength of these bonds in combination is seemingly sufficient to overcome whatever barrier there is to adopting a boat rather than a chair conformation.

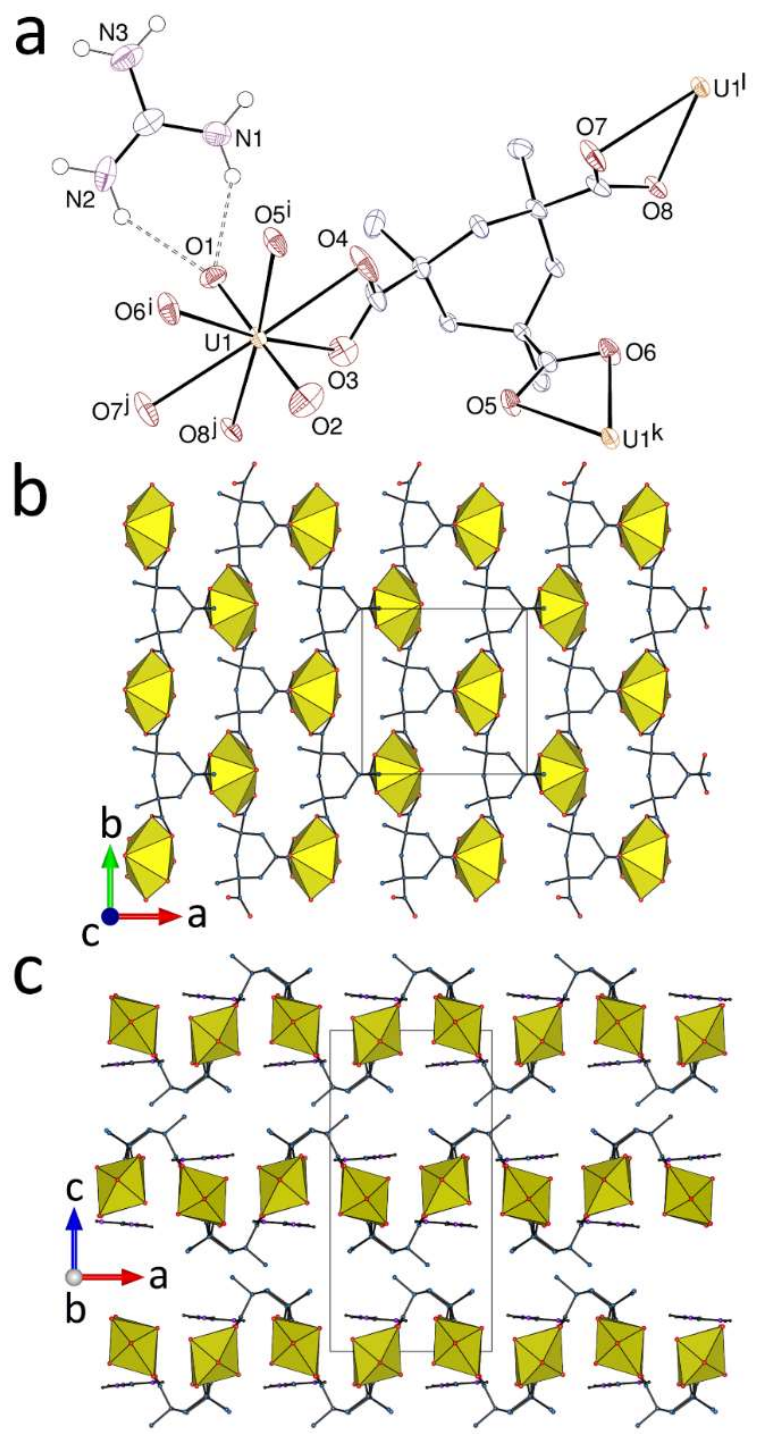

Figure 3. (a) View of compound 3. Displacement ellipsoids are drawn at the $50 \%$ probability level. The carbonbound hydrogen atoms are omitted, and hydrogen bonds are shown as dashed lines. Symmetry codes: $\mathrm{i}=x-1 / 2$, $1 / 2-y, 1-z ; \mathrm{j}=x, y-1, z ; \mathrm{k}=x+1 / 2,1 / 2-y, 1-z ; 1=x, y+1, z$. (b) View of the diperiodic assembly with uranium coordination polyhedra colored yellow. (c) Packing with layers viewed edge-on. 
Two complexes were obtained with d-block metal cations complexed by chelating $N$ donor ligands as counterions, $\left[\mathrm{Cd}(\text { bipy })_{3}\right]\left[\mathrm{UO}_{2}(\mathrm{kta})\right]_{2}(\mathbf{4})$ and $\left[\mathrm{Zn}(\mathrm{phen})_{3}\right]\left[\mathrm{UO}_{2}(\mathrm{kta})\right]_{2} \cdot 2 \mathrm{H}_{2} \mathrm{O}(\mathbf{5})$. Several different metal cations were tested with both bipy and phen ligands, $\mathrm{Cd}^{2+}$ and $\mathrm{Zn}^{2+}$ being those which eventually gave suitable crystalline products. More than the nature of the metal ion itself, the intention here was to check the effect of the difference in bulkiness of the $N$-donors. These cations are like $\mathrm{PPh}_{3} \mathrm{Me}^{+}$and $\mathrm{PPh}_{4}^{+}$in being capable of both aromatic $\cdots$ aromatic and $\mathrm{CH} \cdots \mathrm{O}$ interactions and are not greatly dissimilar to them in size, but the structures of $\mathbf{4}$ and $\mathbf{5}$ are nevertheless distinct from those of $\mathbf{1}$ and $\mathbf{2}$. The unique uranyl cation in $\mathbf{4}$ as well as the four independent uranyl cations in $\mathbf{5}$ are all tris-chelated by three

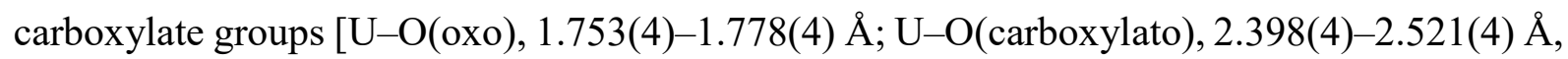
including both compounds], so that here also diperiodic hcb networks are formed, parallel to (100) in 4 and to (010) in 5 (Figures 4 and 5). In both compounds, the kta ${ }^{3-}$ ligands are in the

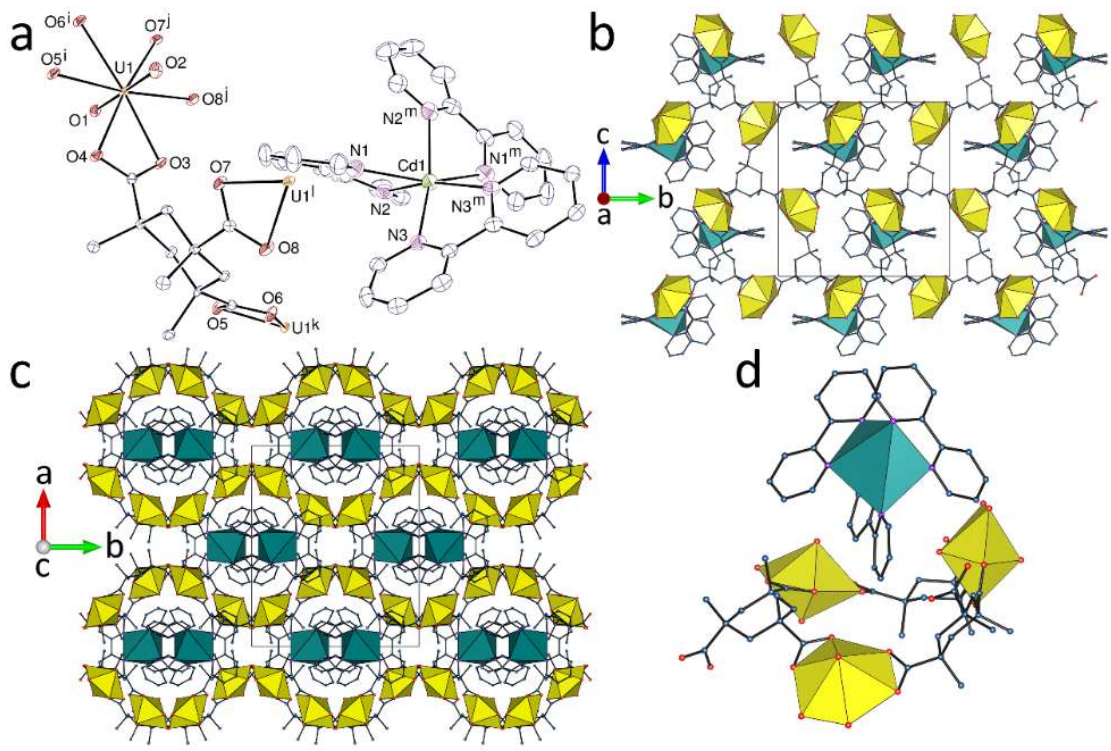

Figure 4. (a) View of compound 4. Displacement ellipsoids are drawn at the 50\% probability level and hydrogen atoms are omitted. Symmetry codes: $\mathrm{i}=x, 1-y, z-1 / 2 ; \mathrm{j}=1 / 2-x, y+1 / 2, z ; \mathrm{k}=x, 1-y, z+1 / 2 ; 1=1 / 2-x, y-$ $1 / 2, z ; \mathrm{m}=-x, y, 3 / 2-z$. (b) View of the diperiodic assembly and the associated counterions with uranium coordination polyhedra colored yellow and those of cadmium green. (c) Packing with layers viewed edge-on. (d) Location of a counterion next to a trinuclear, hexagonal ring. 

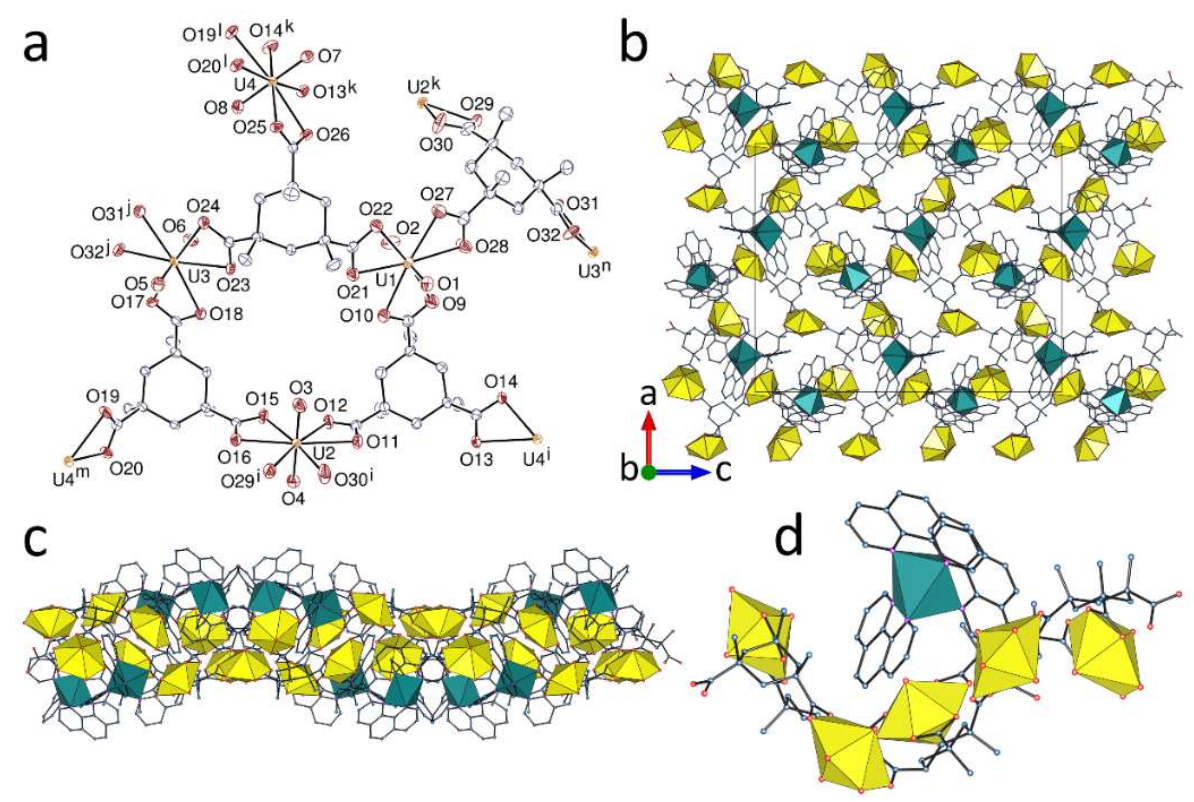

Figure 5. (a) View of compound 5. Displacement ellipsoids are drawn at the 50\% probability level. Counterions, solvent molecules and hydrogen atoms are omitted. Symmetry codes: $\mathrm{i}=x+1 / 2, y, 3 / 2-z ; \mathrm{j}=x, 3 / 2-y, z+1 / 2$; $\mathrm{k}=x-1 / 2, y, 3 / 2-z ; 1=x-1 / 2,3 / 2-y, 2-z ; \mathrm{m}=x+1 / 2,3 / 2-y, 2-z ; \mathrm{n}=x, 3 / 2-y, z-1 / 2$. (b) View of the diperiodic assembly and the associated counterions with uranium coordination polyhedra colored yellow and those of zinc green. (c) One layer viewed edge-on. (d) Location of a counterion in a hollow of the diperiodic network.

chair, eee conformation. The layers in $\mathbf{4}$ are corrugated, with a maximum tilt between equatorial planes of uranyl ions of $74.60(6)^{\circ}$, and they have a thickness of $\sim 9 \AA$ comparable to that in 3 . Here also, they are stacked in hollow-to-hollow fashion and they define quasi-cylindrical channels with a diameter of $\sim 10 \AA$ sufficient to accommodate the counterions. A similar arrangement, with somewhat flattened channels due to the smaller size of the $\left[\mathrm{Ni}(\text { bipy })_{2}\left(\mathrm{H}_{2} \mathrm{O}\right)_{2}\right]^{2+}$ cation, was found with the related 1,3,5-cyclohexanetricarboxylate ligand. ${ }^{55}$ Even more than phosphonium cations in $\mathbf{1}$ and $\mathbf{2}$, the $\left[\mathrm{Cd}(\text { bipy })_{3}\right]^{2+}$ counterion in $\mathbf{4}$ (located on a twofold rotation axis) appears to have a cavity-forming effect, seemingly as a consequence of the larger number of interaction sites present in this octahedral cation. Calculation of short contacts with PLATON does not indicate the presence of parallel $\pi$ stacking interactions within the rows of cations parallel to [001], but the HS reveals the presence 
of numerous $\mathrm{CH} \cdots \mathrm{O}$ hydrogen bonds and $\mathrm{CH} \cdots \pi$ interactions. Overall, the packing is quite compact, with a KPI of 0.72 . The polymeric network in complex $\mathbf{5}$ is less regular, being built from four inequivalent uranyl ions and ligands, and is quasi-planar, but with a thickness of $\sim 9.5$ $\AA$, and it displays hollows in which the $\left[\mathrm{Zn}(\text { phen })_{3}\right]^{2+}$ counterions are embedded (Figure $5 \mathrm{~d}$ ). Here also, no parallel $\pi$-stacking interaction is present, all centroid $\cdots$ centroid distances being larger than $5 \AA$, but the HS evidences the presence of $\mathrm{CH} \cdots \mathrm{O}$ hydrogen bonds and $\mathrm{CH} \cdots \pi$ interactions. The KPI of 0.62 indicates the presence of solvent-accessible voids (see Experimental Section).

The

$$
\left[\mathrm{Co}(\mathrm{en})_{3}\right]^{3+} \quad \text { cation }
$$

found

in

complex

6, $\left[\mathrm{Co}(\mathrm{en})_{3}\right]_{2}\left[\left(\mathrm{UO}_{2}\right)_{2}(\mathrm{kta})(\mathrm{Hkta})_{2}\right]_{2} \cdot 2 \mathrm{NMP} \cdot 10 \mathrm{H}_{2} \mathrm{O}$, is a multiple hydrogen bond donor like guanidinium ion but with a quite different stereochemistry and able to adopt several different conformations. ${ }^{56}$ It is considerably bulkier than guanidinium and may be present in either or both of its stable enantiomeric forms. ${ }^{57}$ All these factors underlie the formation of a very different, closed oligomeric complex involving uranyl ion and both tri- and di-anionic forms of Kemp's triacid in a 2:3 uranyl/ligand ratio rather than the 1:1 seen in complexes 1-5. The anionic complex is centrosymmetric and the two independent uranyl cations are in similar environments, being $\kappa^{2} O, O^{\prime}$-chelated by one carboxylate group, chelated by two carboxylate groups from another ligand, thus forming an 8-membered chelate ring, and bound to one more carboxylate oxygen atom from a third ligand, the uranium coordination environment being thus pentagonal bipyramidal [U-O(oxo), 1.762(4)-1.778(4) Å; U-O(carboxylato), 2.452(4)2.536(4) Å for chelating groups, and 2.283(4)-2.390(4) A for monodentate groups] (Figure 6). The two $\mathrm{Hkta}^{2-}$ ligands are in the chair conformation, but here, unlike what is observed in the diperiodic assemblies, all carboxylic/ate groups are axial ( $a a a)$, in keeping with the reduced level of deprotonation, and this convergent geometry is better suited to the formation of closed 


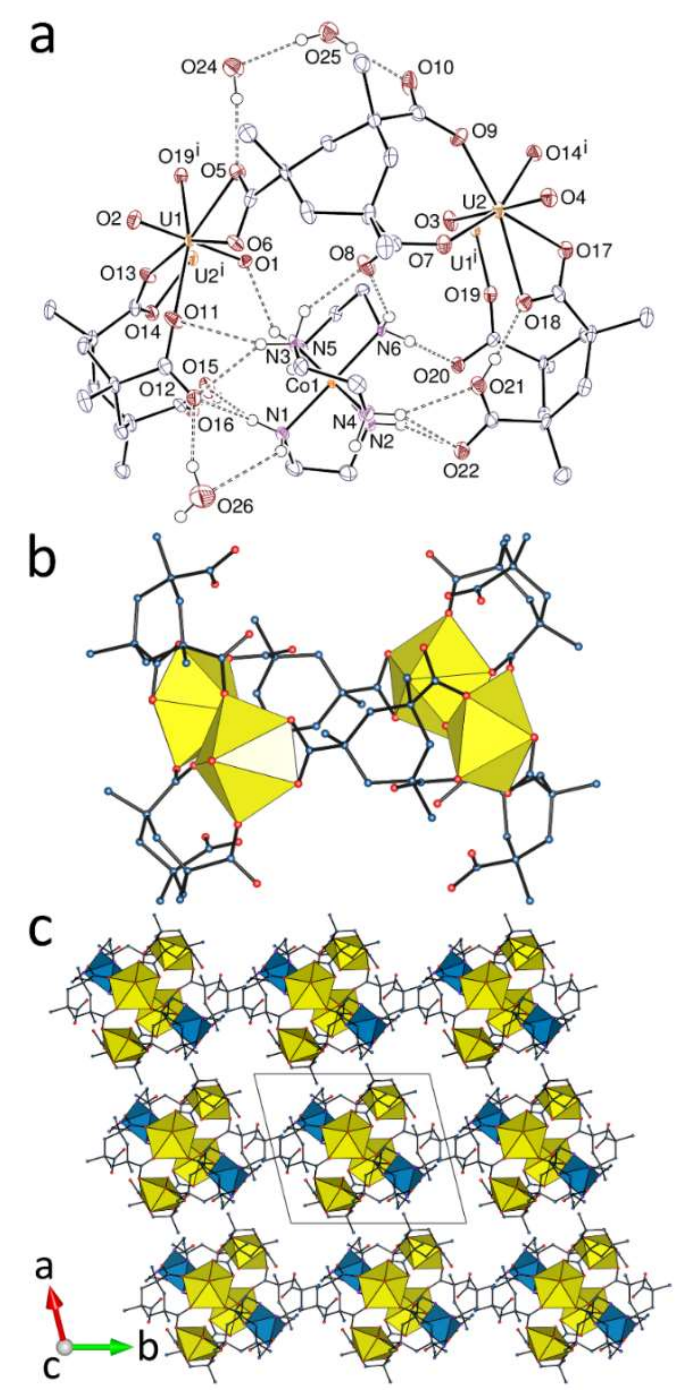

Figure 6. (a) View of compound 6 (only half the tetranuclear unit is represented). Displacement ellipsoids are drawn at the $50 \%$ probability level. Carbon-bound hydrogen atoms are omitted and hydrogen bonds are shown as dashed lines. Symmetry code: $\mathrm{i}=1-x, 1-y, 1-z$. (b) View of the tricyclic, tetranuclear assembly. (c) Packing with uranium coordination polyhedra colored yellow and those of cobalt blue.

species. ${ }^{15,16}$ The carboxylic protons are involved in hydrogen bonding to carboxylate groups in the same complex unit $\left[\mathrm{O} \cdots \mathrm{O}, 2.706(6)\right.$ and $2.511(6) \AA ; \mathrm{O}-\mathrm{H}^{\cdots} \mathrm{O}, 170$ and $\left.168^{\circ}\right]$. In contrast, the $\mathrm{kta}^{3-}$ ligand is in the boat form with two groups equatorial and one axial (eea) and, as in complex $\mathbf{3}$, it can be considered a divergent ligand. While all carboxylate oxygen atoms were coordinated in complexes $\mathbf{1 - 5}$, only about half of them are bound to uranium here, the carboxylic groups in particular being uncoordinated. One carboxylate in the $\mathrm{kta}^{3-}$ ligand is 
$\kappa^{2} O, O^{\prime}$-chelating, and the other two are involved in forming an 8 -membered chelate ring. The two $\mathrm{Hkta}^{2-}$ ligands are differently connected: one is involved in 8-membered ring chelation, with one of the groups being syn/anti $\mu_{2}-\kappa^{1} O: \kappa^{1} O^{\prime}$-bridging, and the other has one group $\kappa^{2} O, O^{\prime}$-chelating and the other monodentate. Two $\mathrm{Hkta}^{2-}$ ligands are associated with two uranyl cations to form a dinuclear, 12-membered ring, and two such rings are linked by two $\mathrm{kta}^{3-}$ ligands to give a centrosymmetric, tetranuclear metallatricyclic species with a larger, 40membered central ring (Figure 7) similar in its geometry to those found in uranyl ion complexes

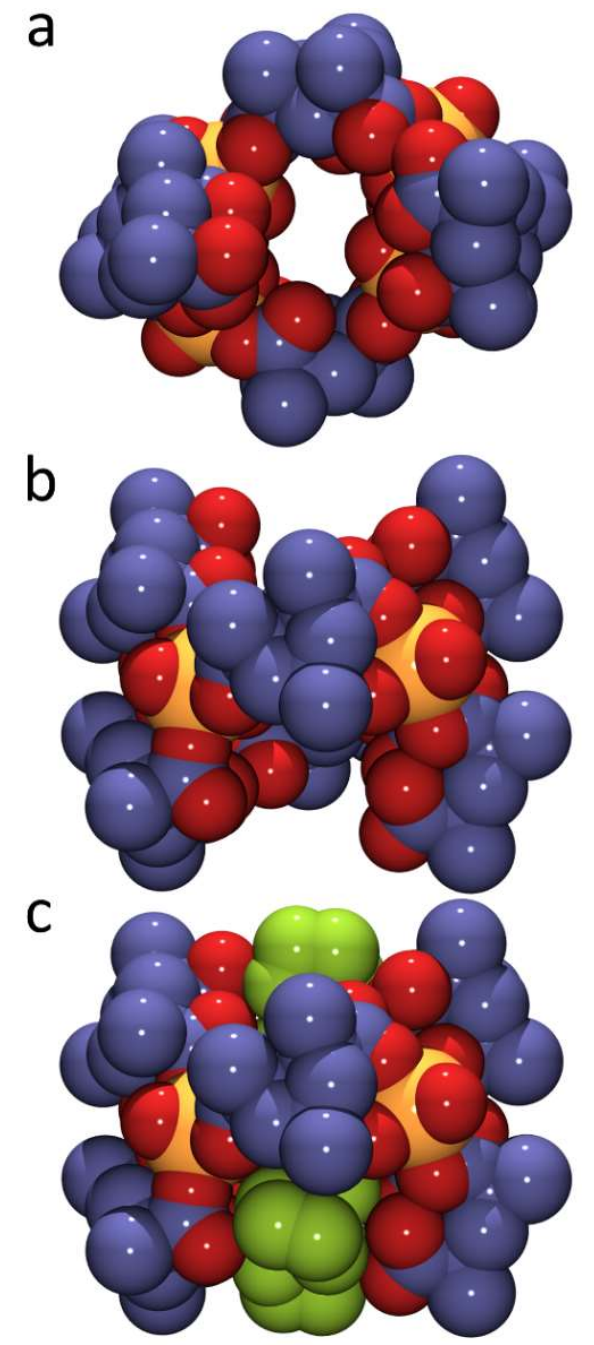

Figure 7. Spacefill representation of the tetranuclear assembly in $\mathbf{6}$ showing the central cavity (a) or viewed sideways either without (b) or with (c) the associated counterions colored green. Hydrogen atoms are omitted. Uranium, yellow; oxygen, red; carbon, blue. 
with 1,3-adamantanediacetate ligands with a mixture of $\mathrm{NH}_{4}{ }^{+}$and either $\mathrm{PPh}_{4}{ }^{+}$or $\mathrm{PPh}_{3} \mathrm{Me}^{+}$ counterions. ${ }^{21}$ The four uranium atoms in $\mathbf{6}$ define a parallelogram with side lengths of 5.0519(3) Å (small ring) and 8.4306(4) Å (large ring), diagonals of 8.7641(5) Å and 10.7882(6) $\AA$, and $\mathrm{U} \cdots \mathrm{U} \cdots \mathrm{U}$ angles of $103.432(4)^{\circ}$ and $76.568(5)^{\circ}$ around $\mathrm{U} 1$ and $\mathrm{U} 2$, respectively. The shape of this parallelogram is similar to that in the 1,3-adamantanediacetate complexes, but the side lengths are smaller (mean values 6.46 and $11.10 \AA$ in the previous complexes). An analogous role to that of ammonium ion in 1,3-adamantanediacetate complexes is played here by the $\left[\mathrm{Co}(\mathrm{en})_{3}\right]^{3+}$ cations which lie to each side of the opening defined by the larger ring, the two associated with any one centrosymmetric macrocycle having enantiomeric configurations. The four uranium and two cobalt atoms form the vertices of a very distorted octahedron

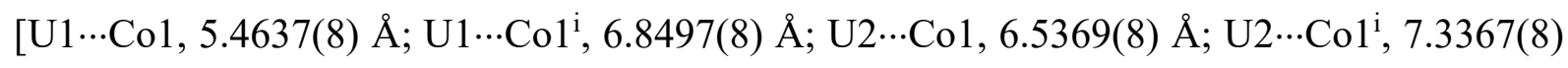
$\left.\AA ; \mathrm{Co} \cdots \mathrm{Co}^{\mathrm{i}}, 8.7597(16) \AA\right]$. The cation has the $l_{2} l_{2} \mathrm{ob}$ conformation, with the $o b$ ring projecting into the macrocyclic hole, and it forms 15 simple or bifurcated hydrogen bonds with carboxylate oxygen atoms, one uranyl oxo group, or water molecules $[\mathrm{N} \cdots \mathrm{O}, 2.824(6)-$ 3.336(7) $\AA ; \mathrm{N}-\mathrm{H} \cdots \mathrm{O}, 122-163^{\circ}$ ]. It is notable that these bonds involve seven out of the eight uncoordinated carboxylate oxygen atoms (four of them twice), atom $\mathrm{O} 10$ being the only exception, so that these atoms, some of them pointing outward, appear to be useful fastening sites for the cations, thus forming two clefts, one on each side of the larger metallacyclic ring. The location of the cation with respect to the HS of the anionic complex and most hydrogen bonding interactions are shown in Figure 8. Once again, multiple hydrogen bonding appears to induce formation of a closed species, as previously found for example in cages or nanotubular complexes built around ammonium cations. ${ }^{20,58}$ It is notable that, in the case of the tricarballylate ligand, the $\left[\mathrm{Co}(\mathrm{en})_{3}\right]^{3+}$ cation promotes the formation of a nanotubular assembly, which is larger than that obtained with ammonium cations. ${ }^{59}$ The close association of anion and cations in 6 results in a compact packing with a KPI of 0.71. 

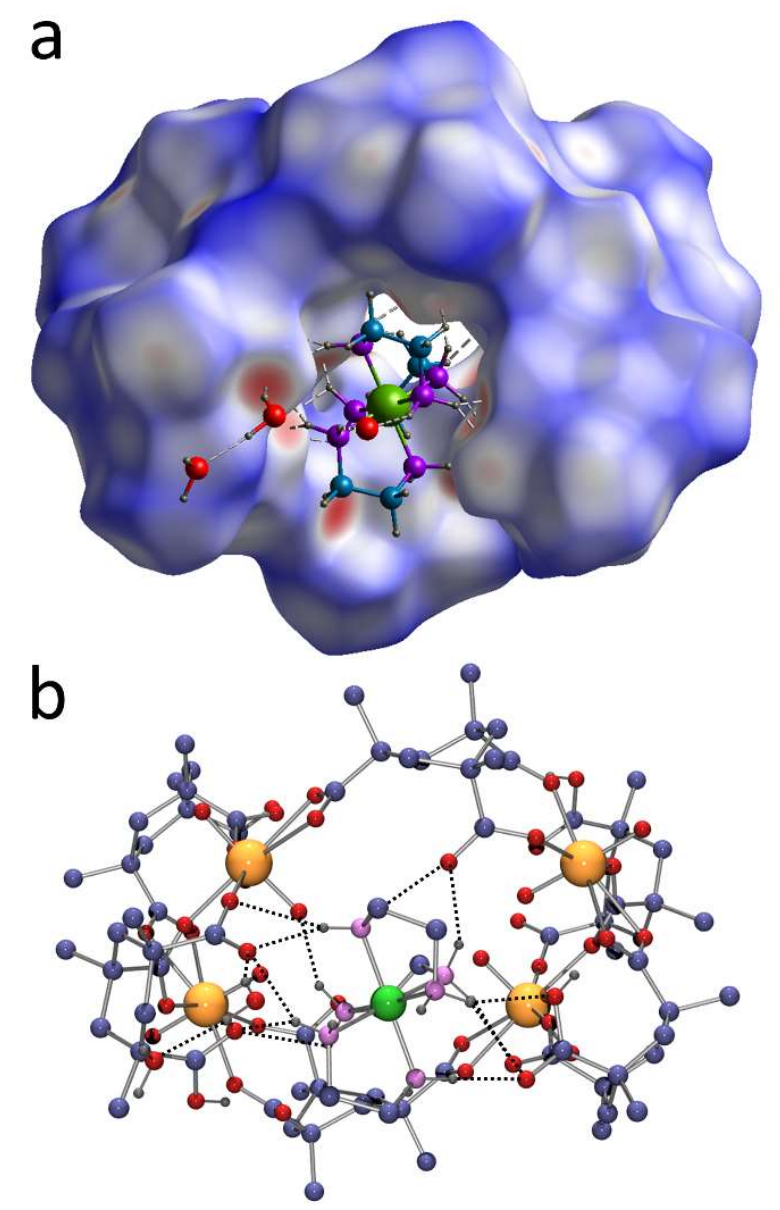

Figure 8. (a) Hirshfeld surface of the anionic uranyl ion complex in $\mathbf{6}$ mapped with $d_{\text {norm. }}$. Hydrogen bonds with one $\left[\mathrm{Co}(\mathrm{en})_{3}\right]^{3+}$ counterion and water molecules are shown as dashed lines. (b) Ball-and-stick view with the same orientation as in (a), with carbon-bound hydrogen atoms omitted for clarity. Uranium, yellow; cobalt, green; oxygen, red; nitrogen, purple; carbon, blue.

The last two complexes, $\quad\left[\left(\mathrm{UO}_{2}\right)_{3} \mathrm{~Pb}(\mathrm{kta})_{2}(\mathrm{Hkta})\left(\mathrm{H}_{2} \mathrm{O}\right)\right]_{2} \cdot 1.5 \mathrm{THF} \quad$ (7) and $\left[\left(\mathrm{UO}_{2}\right)_{2} \mathrm{~Pb}_{2}(\mathrm{kta})_{2}(\mathrm{Hkta})(\mathrm{NMP})\right]_{2}(\mathbf{8})$, are heterometallic species involving additional $\mathrm{Pb}^{\mathrm{II}}$ cations and they crystallize as octanuclear cages, but with a different $\mathrm{U} / \mathrm{Pb}$ ratio. The discrete complex 7 (Figure 9) has no symmetry element, and the six uranium atoms, all in pentagonal bipyramidal environments, form two groups. Atoms U1 to U4 have the same coordination environment as the uranium atoms in $\mathbf{6}$, forming one 4- and one 8-membered chelate rings, with one more carboxylate oxygen donor from a third ligand, while atoms U5 and U6 are part of an 
a
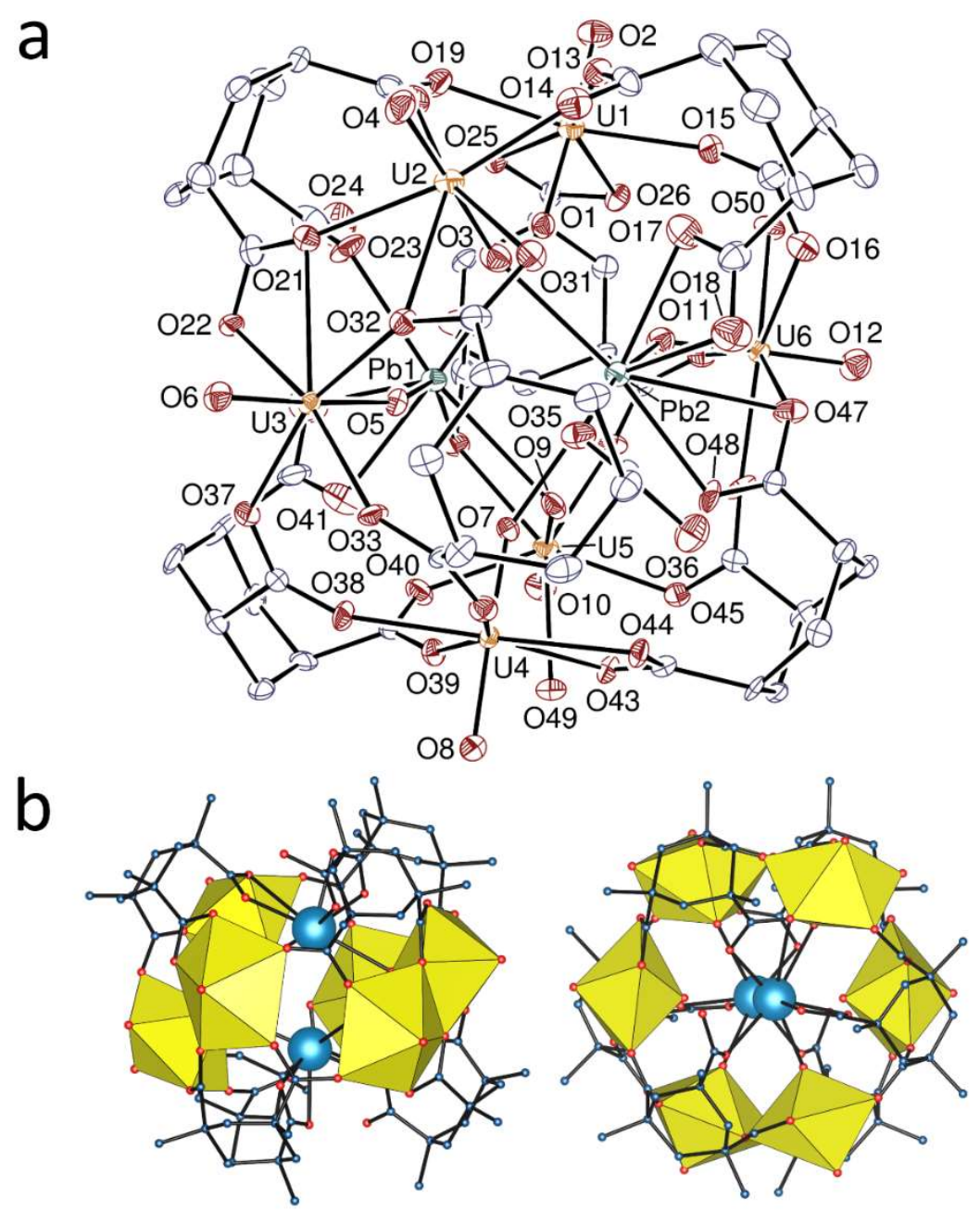

Figure 9. (a) View of compound 7. Displacement ellipsoids are drawn at the $30 \%$ probability level. The methyl groups, minor disordered metal ion positions, solvent molecules and hydrogen atoms are omitted. (b) Two views of the octanuclear cage with uranium coordination polyhedra colored yellow and lead atoms shown as blue spheres.

8-membered chelate ring and are bound to two more oxygen atoms from two more ligands and a water molecule [U-O(oxo), 1.751(12)-1.800(11) Å; U-O(carboxylato), 2.443(9)-2.624(10) $\AA$ for chelating groups, and 2.282(12)-2.436(10) $\AA$ for monodentate groups; U-O(aquo), 2.480(10) and 2.506(10) $\AA$ ]. Determination of lead(II) coordination environments is not always straightforward since it depends on the limit adopted for the longer bonding contacts, ${ }^{60}$ and we have taken here the somewhat arbitrary value of $3.2 \AA$. This results in both lead atoms being in 8-coordinate environments of very irregular geometry (only the major component of the disordered lead centres will be considered in the following). For both cations, the five shorter 
bonds only would give a hemidirected ${ }^{61}$ environment, but the three longer contacts give it a holodirected character. Each lead atom is bound to four carboxylate oxygen atoms $[\mathrm{Pb}-\mathrm{O}$,

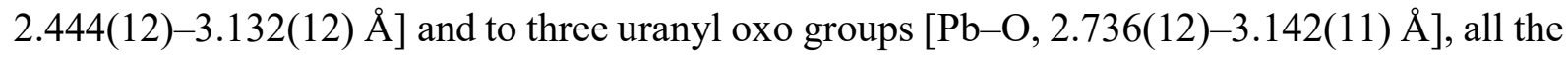
oxo groups directed inwards being thus coordinated. $\mathrm{U}=\mathrm{O}-\mathrm{Pb}$ oxo bonds as short as $\sim 2.5 \AA$ have been found, ${ }^{62}$ but most of those reported match the present range. ${ }^{63-66}$ Of the six independent ligands, four are trianionic and two retain one carboxylic proton, all being in the triaxial chair conformation. One carboxylate group in each ligand (two in one case) is chelating either uranium or lead, with further bridging in some cases $\left(\mu_{2}-\kappa^{2} O, O^{\prime}: \kappa^{1} O\right.$ coordination mode). The other coordinating groups are syn/anti $\mu_{2}-\kappa^{1} O: \kappa^{1} O^{\prime}$ bridges, except for two which are monodentate and are probably the carboxylic groups (the hydrogen atoms were not found, but the two uncoordinated oxygen atoms are at hydrogen bonding distances from the oxygen atoms of the two THF molecules, 2.667(15) and 2.79(2) $\AA$ ). The six uranyl cations and the ligands form a puckered ring, with the two lead(II) cations located at the centre of the two faces, on the pseudo- $S_{3}$ axis (Figure 9b). However, the ligands protruding on each face of the ring give it a globular shape, with a diameter of $\sim 13.5 \AA$ and a height of $\sim 13 \AA$. The overall arrangement is akin to that in the complex $\left[\left(\mathrm{UO}_{2}\right)_{8} \mathrm{Cu}_{4}(\mathrm{kta})_{8}\left(\mathrm{H}_{2} \mathrm{O}\right)_{16}\right] \cdot 9 \mathrm{H}_{2} \mathrm{O},{ }^{16}$ in which the uranyl ions and ligands form a puckered, octanuclear ring, but the copper(II) atoms are located in the mean ring plane and the shape in this case is torus-like. The KPI of 0.60 (with disorder disregarded) indicates the presence of other, unresolved solvent molecules (see Experimental Section).

Complex 8 essentially differs from 7 by replacement of two uranyl by two lead(II) cations. The cage is here centrosymmetric, and the two independent uranyl cations are in different environments, that of U1 being similar to that found in $\mathbf{6}$ and for U1-U4 in 7, with one 4- and one 8-membered chelate rings, and one carboxylate oxygen donor from a third ligand, while U2 forms two 8-membered chelate rings and is bound to one donor from a third ligand, its environment being also pentagonal bipyramidal [U-O(oxo), 1.765(10)-1.806(10) $\AA$; U- 
$\mathrm{O}$ (carboxylato), 2.407(9) and 2.435(10) $\AA$ for the chelating group, and 2.296(9)-2.401(9) $\AA$ for monodentate groups] (Figure 10). The two lead(II) atoms (only the major component of $\mathrm{Pb} 2$ is

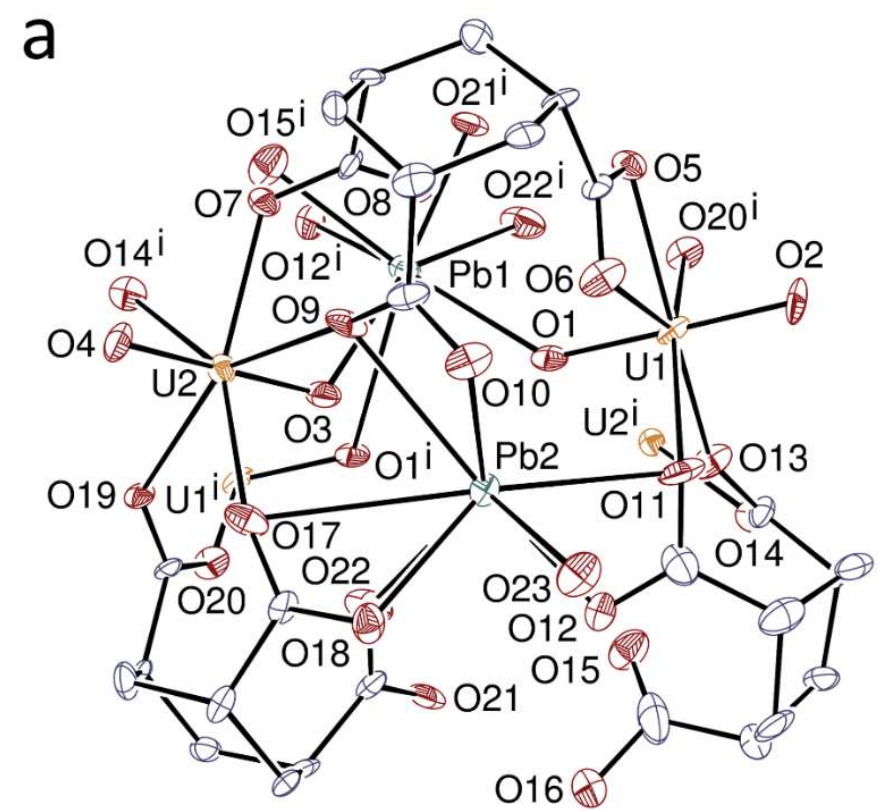

b

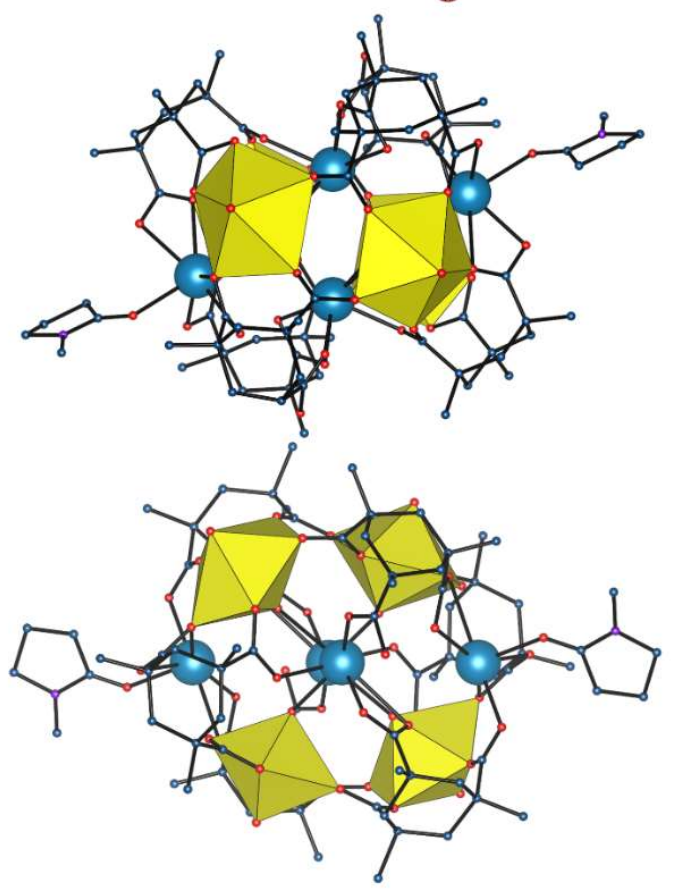

Figure 10. (a) View of compound $\mathbf{8}$ (only half the octanuclear assembly is represented). Displacement ellipsoids are drawn at the 50\% probability level. The methyl groups, minor disordered lead(II) position and hydrogen atoms are omitted. Symmetry code: $\mathrm{i}=3 / 2-x, 1 / 2-y, 1-z$. (b) Two views of the octanuclear cage with uranium coordination polyhedra colored yellow and lead atoms shown as blue spheres. 
considered, see Experimental Section) are here also in 8-coordinate environments of irregular geometry. $\mathrm{Pb} 1$ and its symmetry equivalent, which are the counterparts of the two lead cations in 7, are bound to five carboxylate oxygen atoms [2.348(10)-3.172(14) $\AA]$ and three uranyl oxo groups [2.731(10)-3.060(9) $\AA$ ], while $\mathrm{Pb} 2$ and its image by inversion, which replace two of the uranyl ions in 7, are bound to seven carboxylate donors [2.386(10)-3.160(11) $\AA]$ and one NMP molecule $[2.431(10) \AA]$. The three ligands are in the aaa chair conformation, and display a mixture of the coordination modes found in $7, \kappa^{2} O, O^{\prime}$-chelating, $\mu_{2}-\kappa^{2} O, O^{\prime}: \kappa^{1} O$-chelating and bridging, $\mu_{2}-\kappa^{1} O: \kappa^{1} O^{\prime}$-bridging, and monodentate, the latter being associated to the carboxylic group. The whole assembly can be seen as a heterometallic puckered ring with two lead atoms on the faces, or as containing two homometallic parallelograms, $\mathrm{U}_{4}$ and $\mathrm{Pb}_{4}$, at right angles to one another. Its shape is globular ( 13-14 A between outermost methyl groups), except for the two NMP ligands which point outward to give a $20 \AA$ breadth, and the packing is compact (KPI, 0.69). It is noteworthy that lead(II) alone reacts with Kemp's triacid under solvothermal conditions in $\mathrm{DMF}$ to give the complex $\left[\mathrm{Pb}_{3}(\mathrm{kta})_{2}(\mathrm{DMF})_{3}\right]$, which crystallizes as a diperiodic network involving both eee and aaa chair conformations of the tricarboxylate ligand. ${ }^{27}$ The particular coordination geometry of uranyl ion with Kemp's triacid anions thus appears to be probably essential to cage formation in complexes $\mathbf{7}$ and $\mathbf{8}$ (although of course it cannot be ruled out that, under suitable conditions, a cage compound cannot be obtained with lead(II) alone).

The cage species found in complexes $\mathbf{7}$ and $\mathbf{8}$ expand the family of rings and cages, both homo- and heterometallic, found in uranyl ion complexes of Kemp's triacid anions in the aaa chair conformation. Their relative abundance indicates the ease with which the triaxial ligand conformation may be achieved, although in the present examples the high coordination number and irregular coordination geometry of $\mathrm{Pb}^{\mathrm{II}}$ may be factors favouring the assembly of uranyl carboxylate aggregates into rather compact forms. Complex $\mathbf{6}$ displays a different kind of discrete, metallacyclic complex in which some of the ligands have the divergent boat 
conformation with two carboxylate groups in equatorial position. Nodal representations of the rings and cages obtained up to now with Kemp's triacid anions are shown in Figure 11. It appears that the basic motif in all these species is the rhombus-shaped (but not necessarily planar as seen most clearly in 6) $\left[\mathrm{UO}_{2}(\mathrm{kta} / \mathrm{Hkta})\right]_{2}$ unit, irrespective of the geometry, degree of deprotonation and coordination mode of the ligand. This is at variance with, for example, the distorted octagonal cells found in uranyl ion cage complexes with camphorate ligands. ${ }^{14,22}$ In the simplest arrangement, two such rhombus-shaped cells are connected to one another by two divergent ligands to give the metallatricyclic complex 6. In $\left[\left(\mathrm{UO}_{2}\right)_{8} \mathrm{Cu}_{4}(\mathrm{kta})_{8}\left(\mathrm{H}_{2} \mathrm{O}\right)_{16}\right]{ }^{16}$ eight cells are assembled into a ring which has the topology of an oblique octagonal prism, and the copper centres only play a decorating role. A similar ring is found in $\left[\left(\mathrm{UO}_{2}\right)_{10} \mathrm{Cu}_{6}(\mathrm{kta})_{10}(\mathrm{OH})_{2}\left(\mathrm{H}_{2} \mathrm{O}\right)_{7}\right],{ }^{16}$ but it is here capped on one side by a dome-shaped unit built

a
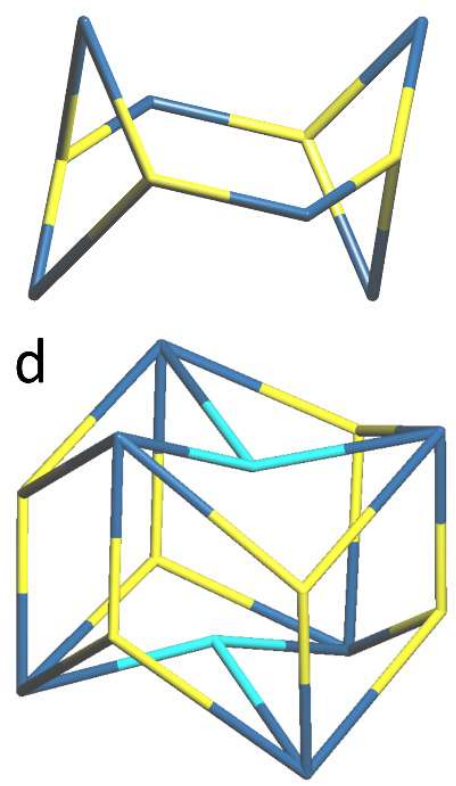

b
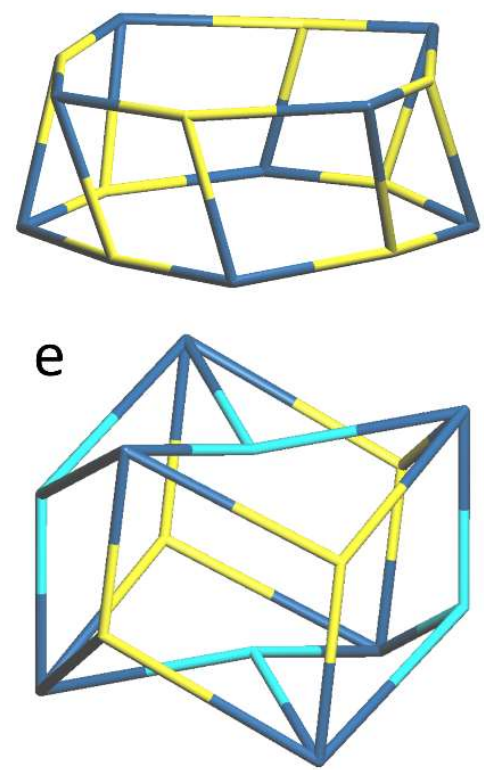

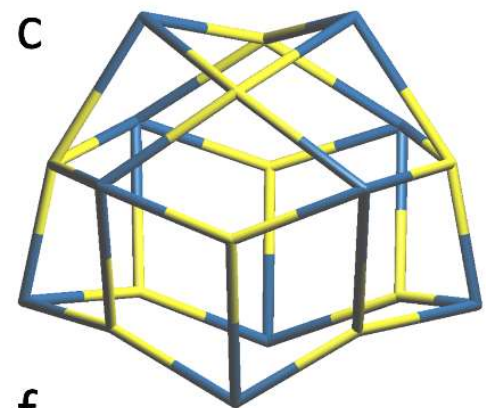

f

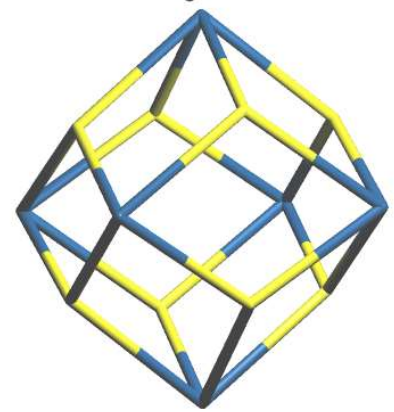

Figure 11. Nodal representation of the polynuclear metallacycles and cages in 6 (a), $\left[\left(\mathrm{UO}_{2}\right)_{8} \mathrm{Cu}_{4}(\mathrm{kta})_{8}\left(\mathrm{H}_{2} \mathrm{O}\right)_{16}\right]$ (b) ${ }^{16}\left[\left(\mathrm{UO}_{2}\right)_{10} \mathrm{Cu}_{6}(\mathrm{kta})_{10}(\mathrm{OH})_{2}\left(\mathrm{H}_{2} \mathrm{O}\right)_{7}\right](\mathrm{c}),{ }^{16} 7$ (d), 8 (e), and $\left.\left[\left(\mathrm{UO}_{2}\right)_{8}(\mathrm{kta})_{6}\left(\mathrm{H}_{2} \mathrm{O}\right)_{6}\right]\right]^{2-}(\mathrm{f}) .{ }^{15}$ Uranium, yellow; lead, light blue; carboxylate ligand, dark blue. The oxo bonds in $\mathrm{d}$ and $\mathrm{e}$, and the decorating copper(II) cations in $\mathrm{b}$ and $\mathrm{c}$ are omitted for clarity. 
from seven cells, to give a decanuclear uranyl unit which further incorporates six copper(II) cations; some of the uranyl and carboxylate ions are here topologically 4-c instead of 3-c only in the previous case. With 14 vertices, 12 rhombic faces and 24 edges, the cages in complexes $\mathbf{7}$ and $\mathbf{8}$ have the topology of a rhombic dodecahedron, but a better description, which puts in evidence the continuity with the two previous shapes, may be as bicapped hexagonal prisms, albeit distorted. In both $\mathbf{7}$ and $\mathbf{8}$, each hexagonal face of the prism is capped by a 3-c lead centre corresponding to three rhombic cells making a concave capping instead of the usual convex one, and two 3-c uranyl ions in the prism are replaced by lead cations in $\mathbf{8}$. Finally, the assembly of twelve quasi-planar rhombic faces gives rise to formation of a fully fledged rhombic dodecahedron in $\left[\left(\mathrm{UO}_{2}\right)_{8}(\mathrm{kta})_{6}\left(\mathrm{H}_{2} \mathrm{O}\right)_{6}\right]^{2-},{ }^{15}$ in which the eight uranyl cations are $3-\mathrm{c}$ and the six carboxylate ligands are 4-c (described as a tetrakis hexahedron in the original publication due to the rhombic faces being divided into two triangles, which may be a more accurate description of the overall shape, but is misleading since it does not take into account the true connectivity of the vertices). This highly symmetrical geometry has been obtained several times, under different conditions and additional cations, ${ }^{15,16}$ which suggests it is a quite stable arrangement.

In contrast to the ubiquitous presence of rhombus-shaped cells in all these closed species, all the diperiodic coordination polymers based on uranyl cations and Kemp's acid trianion, as complexes 1-5 here, and also [Hbipy] $\left[\mathrm{UO}_{2}(\mathrm{kta})\right] \cdot 0.5 \mathrm{H}_{2} \mathrm{O} \cdot 0.25 \mathrm{THF},{ }^{16}\left[\mathrm{H}_{2} \mathrm{NMe}_{2}\right]\left[\mathrm{UO}_{2}(\mathrm{kta})\right],{ }^{29}$ and $\left[\mathrm{UO}_{2} \mathrm{Cs}(\mathrm{kta})\right],{ }^{28}$ contain hexagonal $\left[\mathrm{UO}_{2}(\mathrm{kta})\right]_{3}$ cells and have the hcb topology. However, the larger size of these cells and the flexibility arising from the different conformations of the ligands, chair or boat, the equatorial or axial positioning of the carboxylate groups, and also the varying angle of the ligands with respect to the uranyl equatorial plane, result in a degree of shape modulation. Layers involving ligands in the eee chair conformation vary from gently undulating and separated from one another by quasi-planar layers of counterions as in complex 1, to sawtooth-shaped and providing incipient cavities containing rows of counterions as in $\mathbf{2}$, 
to finally reach a stage where genuine, channel-like cavities are formed through bump-to-bump association of strongly corrugated layers as in $\mathbf{4}$ or $[\mathrm{Hbipy}]\left[\mathrm{UO}_{2}(\mathrm{kta})\right]$. In the last cases, cavity formation is the result of both the corrugated shape of the individual layers and the suitable packing mode. With the eea boat conformation, as found in complexes $\mathbf{3},\left[\mathrm{H}_{2} \mathrm{NMe}_{2}\right]\left[\mathrm{UO}_{2}(\mathrm{kta})\right]$ and $\left[\mathrm{UO}_{2} \mathrm{Cs}(\mathrm{kta})\right]$, the layers formed are always deeply grooved, and their association in bumpto-bump fashion (slightly offset in 3) yields elongated channels which are however occupied by the methyl groups and do not contain any large cation. An overview of all known uranyl ion complexes with Kemp's triacid anions, including the conformation and coordination mode of the ligand, and the geometry of the assembly, is given in Table 2. One conspicuous absence within this family is that of triperiodic frameworks, possibly partly due to the relative ease with which honeycomb networks are built from the divergent form of the ligand, and closed species from the convergent, triaxial form. An investigation of the cis,trans isomer of Kemp's triacid, unfortunately not available, may be of interest here. Obviously also, the hcb network built from the tris-chelating ligand in the eee chair conformation is the most common geometrical type, with some rare variations involving the eea boat form. But the most interesting property of Kemp's triacid in this context is its propensity to form closed species, these being with only one exception heterometallic or involving metal-containing counterions.

The present structure determinations further define two factors which have major influences on the structure of crystalline uranyl carboxylate complexes: ${ }^{7-11}$ hydrogen bonding and competitive metal ion coordination to carboxylate. It is essential to emphasize that this applies to the solid state, since the use of solvo-hydrothermal methods almost universally to obtain crystalline uranyl ion complexes means that generally very little is known of the species present in solution and their interactions under the reaction conditions and thus of any influence they may have on the solubility equilibrium that determines the nature of the isolated product. For pure water, there is certainly evidence that the passage from ambient to supercritical 
Table 2. Overview of Uranyl Ion Complexes with Kemp's Triacid Anions

\begin{tabular}{|c|c|c|c|c|c|}
\hline compound $^{a}$ & $\begin{array}{c}\text { ligand } \\
\text { conformation }^{b}\end{array}$ & $\begin{array}{c}\text { position of } \\
\text { carboxylate } \\
\text { groups }^{b}\end{array}$ & coordination mode ${ }^{b}$ & geometry & ref \\
\hline \multicolumn{6}{|l|}{ 0-periodic, mononuclear } \\
\hline$\left[\mathrm{UO}_{2}\left(\mathrm{ktaH}_{2}\right)_{2}\left(\mathrm{H}_{2} \mathrm{O}\right)_{2}\right]$ & chair & $a a a$ & $\kappa^{2} O, O^{\prime}$ & & 16 \\
\hline \multicolumn{6}{|l|}{ 1-periodic } \\
\hline$\left[\mathrm{UO}_{2}(\mathrm{ktaH})\right]$ & chair & $a a a$ & $\mu_{2}-\kappa^{2} O, O^{\prime}: \kappa^{1} O ; \mu_{2}-\kappa^{1} O: \kappa^{1} O^{\prime}$ & chain & 15 \\
\hline$\left[\left(\mathrm{UO}_{2}\right)_{3}(\mathrm{kta})_{2}(\mathrm{NMP})_{2}\left(\mathrm{H}_{2} \mathrm{O}\right)\right]$ & chair & aaa/eee & $3 \times \mu_{2}-\kappa^{1} O: \kappa^{1} O^{\prime} ; 3 \times \kappa^{2} O, O^{\prime}$ & chain & 15 \\
\hline$\left[\left(\mathrm{UO}_{2}\right)_{2} \mathrm{Ni}(\mathrm{kta})_{2}\left(\mathrm{H}_{2} \mathrm{O}\right)_{4}\right]$ & chair & $a a a$ & $3 \times \mu_{2}-\kappa^{1} O: \kappa^{1} O^{\prime}$ & nanotubular & 15 \\
\hline \multicolumn{6}{|l|}{ 2-periodic } \\
\hline$[\mathrm{Hbipy}]\left[\mathrm{UO}_{2}(\mathrm{kta})\right]$ & chair & eee & $3 \times \kappa^{2} O, O^{\prime}$ & honeycomb network & 16 \\
\hline$\left[\mathrm{PPh}_{3} \mathrm{Me}\right]\left[\mathrm{UO}_{2}(\mathrm{kta})\right]$ & chair & eee & $3 \times \kappa^{2} O, O^{\prime}$ & honeycomb network & this work \\
\hline$\left[\mathrm{PPh}_{4}\right]\left[\mathrm{UO}_{2}(\mathrm{kta})\right]$ & chair & eee & $3 \times \kappa^{2} O, O^{\prime}$ & honeycomb network & this work \\
\hline$\left[\mathrm{Cd}(\text { bipy })_{3}\right]\left[\mathrm{UO}_{2}(\mathrm{kta})\right]_{2}$ & chair & eee & $3 \times \kappa^{2} O, O^{\prime}$ & honeycomb network & this work \\
\hline$\left[\mathrm{Zn}(\mathrm{phen})_{3}\right]\left[\mathrm{UO}_{2}(\mathrm{kta})\right]_{2}$ & chair & eee & $3 \times \kappa^{2} O, O^{\prime}$ & honeycomb network & this work \\
\hline$\left[\mathrm{UO}_{2} \mathrm{~Tb}(\mathrm{kta})(\mathrm{ktaH})\left(\mathrm{H}_{2} \mathrm{O}\right)_{2}\right]$ & chair & $a a a$ & $\kappa^{1} O ; 2 \times \mu_{2}-\kappa^{1} O: \kappa^{1} O^{\prime}$ & heterometallic layer & 16 \\
\hline$\left[\mathrm{H}_{2} \mathrm{NMe}_{2}\right]\left[\mathrm{UO}_{2}(\mathrm{kta})\right]$ & boat & eea & $3 \times \kappa^{2} O, O^{\prime}$ & honeycomb network & 29 \\
\hline$\left[\mathrm{C}\left(\mathrm{NH}_{2}\right)_{3}\right]\left[\mathrm{UO}_{2}(\mathrm{kta})\right]$ & boat & $e e a$ & $3 \times \kappa^{2} O, O^{\prime}$ & honeycomb network & this work \\
\hline$\left[\mathrm{UO}_{2} \mathrm{Cs}(\mathrm{kta})\right]$ & boat & $e e a$ & $2 \times \mu_{2}-\kappa^{2} O, O^{\prime}: \kappa^{1} O ; \kappa^{2} O, O^{\prime}$ & honeycomb network & 28 \\
\hline \multicolumn{6}{|l|}{ 0-periodic, polynuclear } \\
\hline \multirow[t]{3}{*}[\mathrm{Co}(\mathrm{en})_{3}]{$_{2}\left[\left(\mathrm{UO}_{2}\right)_{2}(\mathrm{kta})(\mathrm{Hkta})_{2}\right]_{2}$} & chair/boat & aaa/eea & $\kappa^{1} O ; \kappa^{2} O, O^{\prime}$ & metallatricycle & this work \\
\hline & & & $\mu_{2}-\kappa^{1} O: \kappa^{1} O^{\prime} ; \kappa^{1} O$ & & \\
\hline & & & $2 \times \kappa^{1} O ; \kappa^{2} O, O^{\prime}$ & & \\
\hline$\left[\left(\mathrm{UO}_{2}\right)_{8} \mathrm{Cu}_{4}(\mathrm{kta})_{8}\left(\mathrm{H}_{2} \mathrm{O}\right)_{16}\right]$ & chair & $a a a$ & $\kappa^{1} O ; 2 \times \mu_{2}-\kappa^{1} O: \kappa^{1} O^{\prime}$ & octagonal prism ${ }^{c}$ & 16 \\
\hline \multirow[t]{3}{*}[(\mathrm{UO}_{2})_{10}\mathrm{Cu}_{6}(\mathrm{kta})_{10}(\mathrm{OH})_{2}(\mathrm{H}_{2}\mathrm{O})_{7}]{} & chair & $a a a$ & $3 \times \mu_{2}-\kappa^{1} O: \kappa^{1} O^{\prime}$ & dome-capped octagonal prism ${ }^{c}$ & 16 \\
\hline & & & $2 \times \mu_{2}-\kappa^{1} O: \kappa^{1} O^{\prime} ; \kappa^{2} O, O^{\prime}$ & & \\
\hline & & & $2 \times \mu_{2}-\kappa^{1} O: \kappa^{1} O^{\prime} ; \mu_{2}-\kappa^{2} O, O^{\prime}: \kappa^{1} O$ & & \\
\hline \multirow[t]{3}{*}[(\mathrm{UO}_{2})_{3}\mathrm{Pb}(\mathrm{kta})_{2}(\mathrm{Hkta})(\mathrm{H}_{2}\mathrm{O})]{$_{2}$} & chair & $a a a$ & $\mu_{2}-\kappa^{2} O, O^{\prime}: \kappa^{1} O ; \mu_{2}-\kappa^{1} O: \kappa^{1} O^{\prime} ; \kappa^{2} O, O^{\prime}$ & bicapped hexagonal prism & this work \\
\hline & & & $\mu_{2}-\kappa^{2} O, O^{\prime}: \kappa^{1} O ; \mu_{2}-\kappa^{1} O: \kappa^{1} O^{\prime} ; \kappa^{1} O$ & & \\
\hline & & & $2 \times \mu_{2}-\kappa^{1} O: \kappa^{1} O^{\prime} ; \kappa^{2} O, O^{\prime}$ & & \\
\hline \multirow[t]{3}{*}[(\mathrm{UO}_{2})_{2}\mathrm{Pb}_{2}(\mathrm{kta})_{2}(\mathrm{Hkta})(\mathrm{NMP})]{$_{2}$} & chair & $a a a$ & $\mu_{2}-\kappa^{2} O, O^{\prime}: \kappa^{1} O ; \mu_{2}-\kappa^{1} O: \kappa^{1} O^{\prime} ; \kappa^{2} O, O^{\prime}$ & bicapped hexagonal prism & this work \\
\hline & & & $\mu_{2}-\kappa^{2} O, O^{\prime}: \kappa^{1} O ; \mu_{2}-\kappa^{1} O: \kappa^{1} O^{\prime} ; \kappa^{1} O$ & & \\
\hline & & & $2 \times \mu_{2}-\kappa^{1} O: \kappa^{1} O^{\prime} ; \kappa^{2} O, O^{\prime}$ & & \\
\hline$[\mathrm{CI}]\left[\left(\mathrm{UO}_{2}\right)_{8}(\mathrm{kta})_{6}\left(\mathrm{H}_{2} \mathrm{O}\right)_{6}\right]^{d}$ & chair & $a a a$ & $2 \times \mu_{2}-\kappa^{1} O: \kappa^{1} O^{\prime} ; \kappa^{2} O, O^{\prime}$ & rhombic dodecahedron & 15,16 \\
\hline$\left[\left(\mathrm{UO}_{2}\right)_{8}\left\{(\mathrm{kta})_{6} \mathrm{H}_{2}\right\}\left(\mathrm{H}_{2} \mathrm{O}\right)_{6}\right]$ & chair & $a a a$ & $2 \times \mu_{2}-\kappa^{1} O: \kappa^{1} O^{\prime} ; \kappa^{2} O, O^{\prime}$ & rhombic dodecahedron & 16 \\
\hline
\end{tabular}

${ }^{a}$ Solvent molecules are omitted for clarity. ${ }^{b}$ Given for each carboxylate group and/or for all inequivalent ligands if applicable. ${ }^{c}$ Decorating copper(II) cations omitted. ${ }^{d} \mathrm{CI}=\mathrm{Ni}($ bipy $)\left(\mathrm{H}_{2} \mathrm{O}\right)_{4}$ or $\mathrm{Cu}_{2}\left(\mathrm{C}_{2} \mathrm{O}_{4}\right)(\text { bipy })_{2}(\mathrm{THF})_{2}$.

conditions can have a major influence on solution equilibria, ${ }^{67}$ but there are no such data for mixed solvents as used herein. Thus, from consideration of the structures of $\mathbf{1 , 2 , 4}$ and $\mathbf{5}$, it might be concluded that full deprotonation of Kemp's triacid favours the eee conformation with $\kappa^{2} O, O^{\prime}$ binding of carboxylate to uranyl and thus the formation of diperiodic uranyl ion 
polymers but the fact that complexes $\mathbf{6 , 7}$ and $\mathbf{8}$ contain some incompletely deprotonated ligands indicates that various forms may be present in solution. While it may seem obvious that the trianion could be made dominant by the addition of a base, such a procedure in general leads to uranyl ion hydrolysis and the isolation of crystals containing oxo/hydroxo oligomers. Thus, the more delicate procedure of adding weak $(\mathrm{CH})$ hydrogen bond donors to the reaction mixtures appears to be the most effective method for obtaining uranyl ion complexes of the fully deprotonated acid in its eee conformation. Strong (NH) hydrogen bond donors clearly perturb this situation but the very different consequences observed in the present instances of complexes $\mathbf{3}$ and $\mathbf{6}$ show there is a much greater sensitivity to the stereochemistry of the donor than is apparent here for the weak donor species. Presumably, the competition between uranyl ion and the proton is a factor influencing all these structures and it appears that if the $\kappa^{2} O, O^{\prime}$ binding mode of carboxylate to uranyl ion can be disrupted, either by strong hydrogen bonding in the case of complex $\mathbf{6}$ or $\mathrm{Pb}^{\mathrm{II}}$ coordination as in complexes $\mathbf{7}$ and $\mathbf{8}$, a consequence may be the favouring of the triaxial conformation and hence that of the formation of closed species. The structure of complex $\mathbf{3}$, however, shows that a different response to strong hydrogen bonding may be that of a conformational change, a reflection of the rather remarkable flexibility of Kemp's triacid and its anions.

\section{CONCLUSIONS}

Eight uranyl ion complexes with Kemp's triacid di- or trianions have been synthesized and characterized by crystal structure determination. Five of them crystallize as diperiodic networks with honeycomb (hcb) topology, but the different conformations adopted by the ligands, either chair with the three coordinating groups equatorial, or boat with two groups equatorial and one axial, and the structure-directing effect of the counterions (phosphoniums, guanidinium, dblock metal complexes with bipy or phen) result in variations in the degree of corrugation of 
the layers. In some instances, the bump-to-bump, hollow-to-hollow packing mode of the grooved layers produces quasi-cylindrical channels. The third Kemp's di-/tricarboxylate conformation observed is the chair with all carboxylate groups axial, which turns the ligand into a tripodal, convergent linker particularly well suited to the formation of closed species (although it is found also in some simple zero- and monoperiodic complexes). Besides the nanotubes, rings and cages previously reported, the present series provides three examples of such compounds. With the hydrogen bonding counterion $\left[\mathrm{Co}(\mathrm{en})_{3}\right]^{3+}$, a tetranuclear uranyl metallatricycle displaying two clefts containing the counterions is formed, which is akin to a species previously obtained with 1,3-adamantanediacetate ligands and different, organic counterions. Introduction of lead(II) additional cations yields two octanuclear cages with a different $\mathrm{U} / \mathrm{Pb}$ ratio, depending on the experimental conditions. Both share however a common geometry which can best be described as a bicapped hexagonal prism, albeit concave at the capping positions occupied by $\mathrm{Pb}^{\mathrm{II}}$ cations (two more lead centres replacing two uranyl cations in the prismatic part of one of the complexes). Both uranyl and lead cations contribute to the formation of the cage, and they are also directly linked to one another through numerous $\mathrm{U}=\mathrm{O}-$ $\mathrm{Pb}$ oxo bonds. These closed species are compared with those previously reported, all containing more or less distorted rhombic faces in their nodal representation, leading to two main groups of prismatic (capped or not), or rhombic dodecahedral species. In association with uranyl cations, Kemp's tricarboxylate in its tripodal form thus appears to be uncommonly suitable for generating metallacycles or cages, with a fair possibility of modulations through variations in synthetic conditions. 


\section{ASSOCIATED CONTENT}

\section{Accession Codes}

CCDC 2037808-2037815 contain the supplementary crystallographic data for this paper. These data can be obtained free of charge via www.ccdc.cam.ac.uk/data_request/cif, or by emailing data_request@ccdc.cam.ac.uk, or by contacting The Cambridge Crystallographic Data Centre, 12 Union Road, Cambridge CB2 1EZ, UK; fax: +44 1223336033.

\section{AUTHOR INFORMATION}

\section{Corresponding Authors}

*E-mail: pierre.thuery@cea.fr. (P.T.)

*E-mail: harrowfield@unistra.fr. (J.H.)

\section{ORCID}

Pierre Thuéry: 0000-0003-1683-570X

Jack Harrowfield: 0000-0003-4005-740X

\section{Notes}

The authors declare no competing financial interest.

\section{REFERENCES}

1 Qiu, J.; Burns, P. C. Clusters of Actinides with Oxide, Peroxide, or Hydroxide Bridges. Chem. Rev. 2013, 113, 1097-1120.

2 Ling, J.; Hobbs, F.; Prendergast, S.; Adelani, P. O.; Babo, J. M.; Qiu, J.; Weng, Z.; Burns, P. C. Hybrid Uranium-Transition-Metal Oxide Cage Clusters. Inorg. Chem. 2014, 53, $12877-12884$. 
3 Sigmon, G. E.; Szymanowski, J. E. S.; Carter, K. P.; Cahill, C. L.; Burns, P. C. Hybrid Lanthanide-Actinide Peroxide Cage Clusters. Inorg. Chem. 2016, 55, 2682-2684.

4 Dembowski, M.; Olds, T. A.; Pellegrini, K. L.; Hoffmann, C.; Wang, X.; Hickam, S.; He, J.; Oliver, A. G.; Burns, P. C. Solution ${ }^{31}$ P NMR Study of the Acid-Catalyzed Formation of a Highly Charged $\left\{\mathrm{U}_{24} \mathrm{Pp}_{12}\right\}$ Nanocluster, $\left[\left(\mathrm{UO}_{2}\right)_{24}\left(\mathrm{O}_{2}\right)_{24}\left(\mathrm{P}_{2} \mathrm{O}_{7}\right)_{12}\right]^{48-}$, and Its Structural Characterization in the Solid State Using Single-Crystal Neutron Diffraction. J. Am. Chem. Soc. 2016, $138,8547-8553$.

5 Hickam, S.; Burns, P. C. Oxo Clusters of $5 f$ Elements. Struct. Bonding (Berlin, Ger.) 2017, 173, 121-154.

6 Pasquale, S.; Sattin, S.; Escudero-Adán, E. C.; Martínez-Belmonte, M.; de Mendoza, J. Giant Regular Polyhedra from Calixarene Carboxylates and Uranyl. Nature Commun. 2012, 3, 785791.

7 Wang, K. X.; Chen, J. S. Extended Structures and Physicochemical Properties of UranylOrganic Compounds. Acc. Chem. Res. 2011, 44, 531-540.

8 Andrews, M. B.; Cahill, C. L. Uranyl Bearing Hybrid Materials: Synthesis, Speciation, and Solid-State Structures. Chem. Rev. 2013, 113, 1121-1136.

9 Loiseau, T.; Mihalcea, I.; Henry, N.; Volkringer, C. The Crystal Chemistry of Uranium Carboxylates. Coord. Chem. Rev. 2014, 266-267, 69-109.

$10 \mathrm{Su}, \mathrm{J}$;; Chen, J. S. MOFs of Uranium and the Actinides. Struct. Bond. 2015, 163, 265-296.

11 Thuéry, P.; Harrowfield, J. Recent Advances in Structural Studies of Heterometallic UranylContaining Coordination Polymers and Polynuclear Closed Species. Dalton Trans 2017, 46, 13660-13667.

12 Thuéry, P.; Nierlich, M.; Baldwin, B. W.; Komatsuzaki, N.; Hirose, T. A Metal-Organic Molecular Box Obtained from Self-Assembling around Uranyl Ions. J. Chem. Soc., Dalton Trans., 1999, 1047-1048. 
13 Thuéry, P.; Villiers, C.; Jaud, J.; Ephritikhine, M.; Masci, B. Uranyl-Based Metallamacrocycles: Tri- and Tetranuclear Complexes with $(2 R, 3 R, 4 S, 5 S)$ Tetrahydrofurantetracarboxylic Acid. J. Am. Chem. Soc. 2004, 126, 6838-6839.

14 Thuéry, P. A Nanosized Uranyl Camphorate Cage and its Use as a Building Unit in a MetalOrganic Framework. Cryst. Growth Des. 2009, 9, 4592-4594.

15 Thuéry, P. A Highly Adjustable Coordination System: Nanotubular and Molecular Cage Species in Uranyl Ion Complexes with Kemp's Triacid. Cryst. Growth Des. 2014, 14, 901-904. 16 Thuéry, P. Increasing Complexity in the Uranyl Ion-Kemp's Triacid System: From One- and Two-Dimensional Polymers to Uranyl-Copper(II) Dodeca- and Hexadecanuclear Species. Cryst. Growth Des. 2014, 14, 2665-2676.

17 Thuéry, P.; Harrowfield, J. A New Form of Triple-Stranded Helicate Found in Uranyl Complexes of Aliphatic $\alpha, \omega$-Dicarboxylates. Inorg. Chem. 2015, 54, 10539-10541.

18 Thuéry, P.; Harrowfield, J. Coordination Polymers and Cage-Containing Frameworks in Uranyl Ion Complexes with rac- and (1R,2R)-trans-1,2-Cyclohexanedicarboxylates: Consequences of Chirality. Inorg. Chem. 2017, 56, 1455-1469.

19 Thuéry, P.; Harrowfield, J. Tetrahedral and Cuboidal Clusters in Complexes of Uranyl and Alkali or Alkaline-Earth Metal Ions with rac- and (1R,2R)-trans-1,2Cyclohexanedicarboxylate. Cryst. Growth Des. 2017, 17, 2881-2892.

20 Thuéry, P.; Atoini, Y.; Harrowfield, J. Counterion-Controlled Formation of an Octanuclear Uranyl Cage with cis-1,2-Cyclohexanedicarboxylate Ligands. Inorg. Chem. 2018, 57, 62836288.

21 Thuéry, P.; Atoini, Y.; Harrowfield, J. Closed Uranyl-Dicarboxylate Oligomers: A Tetranuclear Metallatricycle with Uranyl Bridgeheads and 1,3-Adamantanediacetate Linkers. Inorg. Chem. 2018, 57, 7932-7939. 
22 Thuéry, P.; Atoini, Y.; Harrowfield, J. Chiral Discrete and Polymeric Uranyl Ion Complexes with $(1 R, 3 S)-(+)$-Camphorate Ligands: Counterion-Dependent Formation of a Hexanuclear Cage. Inorg. Chem. 2019, 58, 870-880.

23 Kemp, D. S.; Petrakis, K. S. Synthesis and Conformational Analysis of cis,cis-1,3,5Trimethylcyclohexane-1,3,5-tricarboxylic Acid. J. Org. Chem. 1981, 46, 5140-5143.

24 Wintner, E. A.; Conn, M. M.; Rebek, J., Jr. Studies in Molecular Replication. Acc. Chem. Res. 1994, 27, 198-203.

25 Takemura, Y.; Okui, Y.; Kure, B.; Nakajima, T.; Tanase, T.; Mikuriya, M.; Takahashi, M. Octanuclear Iron(III) Complexes Supported by Kemp's Tricarboxylate Ligands. Inorg. Chim. Acta 2011, 379, 100-108.

26 Okui, Y.; Catusanu, F. A.; Kubota, R.; Kure, B.; Nakajima, T.; Tanase, T.; Kajiwara, T.; Mikuriya, M.; Miyasaka, H.; Yamashita, M. Systematic Expansion of Supercubane Cores in Manganese Oxo Clusters with Tricarboxylate Ligands. Eur. J. Inorg. Chem. 2011, 4325-4330.

27 Kim, S. B.; Lee, D. W.; Chang, S. K.; Ok, K. M. $\mathrm{Pb}_{3}\left[\mathrm{C}_{6}\left(\mathrm{CH}_{3}\right)_{3}\left(\mathrm{CO}_{2}\right)_{3} \mathrm{H}_{6}\right]_{2}[\mathrm{DMF}]_{3}$ : First Layered Pb-Kemp's Triacid Complex. Chem. Commun. 2015, 51, 13166-13169.

28 Harrowfield, J.; Thuéry, P. Dipodal, Tripodal and Discoidal Coordination Modes of Kemp's Triacid Anions. Eur. J. Inorg. Chem. 2020, 749-756.

29 Thuéry, P.; Harrowfield, J. Two-dimensional Assemblies in f-Element Ion $\left(\mathrm{UO}_{2}{ }^{2+}, \mathrm{Yb}^{3+}\right)$ Complexes with two Cyclohexyl-Based Polycarboxylates. Polyhedron 2015, 98, 5-11.

30 Han, J.; Zang, S. Q.; Mak, T. C. W. Controlled Aggregation of Multiple Guanidinium Ions through a Hydrogen-Bonded Network Assembly with Deprotonated Forms of Kemp's Triacid. Chem. Eur. J. 2010, 16, 5078-5088.

31 Huczyński, A.; Janczak, J.; Brzezinski, B. Crystals of the Kemp’s triacid salts - Part VI: Supramolecular Architecture in the Crystal of Kemp's Triacid with Tris(2-aminoethyl)amine. J. Mol. Struct. 2011, 996, 48-52. 
32 APEX3 Crystallography Software Suite, Ver. 2019.1-0; Bruker AXS: Madison, WI, USA, 2019.

33 SAINT, Ver. 8.40A; Bruker Nano: Madison, WI, USA, 2019.

34 SADABS, Bruker/Siemens Area Detector Absorption and Other Corrections, Ver. 2016/2; Bruker AXS: Madison, WI, USA, 2016.

35 Krause, L.; Herbst-Irmer, R.; Sheldrick, G. M.; Stalke, D. Comparison of Silver and Molybdenum Microfocus X-Ray Sources for Single-Crystal Structure Determination. J. Appl. Crystallogr. 2015, 48, 3-10.

36 Sheldrick, G. M. SHELXT - Integrated Space-Group and Crystal-Structure Determination. Acta Crystallogr., Sect. A 2015, 71, 3-8.

37 Sheldrick, G. M. Crystal Structure Refinement with SHELXL. Acta Crystallogr., Sect. C 2015, $71,3-8$.

38 Hübschle, C. B.; Sheldrick, G. M.; Dittrich, B. ShelXle: a Qt Graphical User Interface for SHELXL. J. Appl. Crystallogr. 2011, 44, 1281-1284.

39 Farrugia, L. J. WinGX and ORTEP for Windows: an Update. J. Appl. Crystallogr. 2012, 45, 849-854.

40 Momma, K.; Izumi, F. VESTA 3 for Three-Dimensional Visualization of Crystal, Volumetric and Morphology Data. J. Appl. Crystallogr. 2011, 44, 1272-1276.

41 Blatov V. A.; Shevchenko, A. P.; Proserpio, D. M. Applied Topological Analysis of Crystal Structures with the Program Package ToposPro. Cryst. Growth Des. 2014, 14, 3576-3586.

42 Spek, A. L. PLATON SQUEEZE: a Tool for the Calculation of the Disordered Solvent Contribution to the Calculated Structure Factors. Acta Crystallogr., Sect. C 2015, 71, 9-18.

43 Bencini, A.; Bianchi, A.; Burguete, M. A.; Dapporto, P.; Doménech, A.; García-España, E.; Luis, S. V.; Paoli, P.; Ramírez, J. A. Selective Recognition of Carboxylate Anions by 
Polyammonium Receptors in Aqueous Solution. Criteria for Selectivity in Molecular Recognition. J. Chem. Soc., Perkin Trans. 2 1994, 569-577.

44 Thuéry, P.; Nierlich, M.; Baldwin, B. W.; Aoki, Y.; Hirose, T. Conformation of cis,trans-1,3,5Trimethylcyclohexane-1,3,5-tricarboxylic Acid Derivatives: Crystal Structures and Semiempirical Molecular Orbital Calculations. J. Chem. Soc., Perkin Trans. 2 1999, 20772082.

45 Menger, F. M.; Chicklo, P. A.; Sherrod, M. J. Ion-Induced Conformational Changes in Kemp's Triacid. Tetrahedron Lett. 1989, 30, 6943-6946.

46 Thuéry, P.; Atoini, Y.; Harrowfield, J. 1,3-Adamantanedicarboxylate and 1,3adamantanediacetate as Uranyl Ion Linkers: Effect of Counterions, Solvents and Differences in Flexibility. Eur. J. Inorg. Chem. 2019, 4440-4449.

47 Dance, I.; Scudder, M. Supramolecular Motifs: Concerted Multiple Phenyl Embraces between $\mathrm{Ph}_{4} \mathrm{P}^{+}$Cations are Attractive and Ubiquitous. Chem. Eur. J. 1996, 2, 481-486.

48 Spackman, M. A.; Jayatilaka, D. Hirshfeld Surface Analysis. CrystEngComm 2009, 11, 1932.

49 Wolff, S. K.; Grimwood, D. J.; McKinnon, J. J.; Turner, M. J.; Jayatilaka, D.; Spackman, M. A. CrystalExplorer, University of Western Australia, 2012.

50 Taylor, R.; Kennard, O. Crystallographic Evidence for the Existence of C-H $\cdots \mathrm{O}, \mathrm{C}-\mathrm{H} \cdots \mathrm{N}$, and C-H‥Cl Hydrogen Bonds. J. Am. Chem. Soc. 1982, 104, 5063-5070.

51 Desiraju, G. R. The C-H‥O Hydrogen Bond: Structural Implications and Supramolecular Design. Acc. Chem. Res. 1996, 29, 441-449.

52 Spek, A. L. Structure Validation in Chemical Crystallography. Acta Crystallogr., Sect. D 2009, $65,148-155$.

53 Etter, M. C.; MacDonald, J. C.; Bernstein, J. Graph-Set Analysis of Hydrogen-Bond Patterns in Organic Crystals. Acta Crystallogr., Sect. B 1990, 46, 256-262. 
54 Bernstein, J.; Davis, R. E.; Shimoni, L.; Chang, N. L. Patterns in Hydrogen Bonding: Functionality and Graph Set Analysis in Crystals. Angew. Chem. Int. Ed. 1995, 34, 1555-1573. 55 Thuéry, P.; Harrowfield, J. Uranyl Ion Complexes with all-cis-1,3,5Cyclohexanetricarboxylate: Unexpected Framework and Nanotubular Assemblies. Cryst. Growth Des. 2014, 14, 4214-4225.

56 Ghosh, S. K.; Ehnbom, A.; Lewis, K. G.; Gladysz, J. A. Hydrogen Bonding Motifs in Structurally Characterized Salts of the Tris(ethylenediamine) Cobalt Trication, $\left[\operatorname{Co}(\mathrm{en})_{3}\right]^{3+}$; an Interpretive Review, Including Implications for Catalysis. Coord. Chem. Rev. 2017, 350, 3048.

57 Ehnbom, A.; Ghosh, S. K.; Lewis, K. G.; Gladysz, J. A. Octahedral Werner Complexes with Substituted Ethylenediamine Ligands: a Stereochemical Primer for a Historic Series of Compounds Now Emerging as a Modern Family of Catalysts. Chem. Soc. Rev. 2016, 45, 67996811.

58 Thuéry, P.; Harrowfield, J. Variations on the Honeycomb Topology: From Triangular- and Square-Grooved Networks to Tubular Assemblies in Uranyl Tricarballylate Complexes. Cryst. Growth Des. 2017, 17, 963-966.

59 Thuéry, P.; Atoini, Y.; Harrowfield, J. Uranyl Tricarballylate Triperiodic and Nanotubular Species. Counterion Control of Nanotube Diameter. Inorg. Chem. 2020, 59, 6953-6962.

60 Harrowfield, J. The Enigma of Lead(II) Coordination - Some Comments. Helv. Chim. Acta 2005, $88,2430-2432$.

61 Shimoni-Livny, L.; Glusker, J. P.; Bock, C. W. Lone Pair Functionality in Divalent Lead Compounds. Inorg. Chem. 1998, 37, 1853-1867.

62 Bell, N. L.; Arnold, P. L.; Love, J. B. Controlling Uranyl Oxo Group Interactions to Group 14 Elements Using Polypyrrolic Schiff-Base Macrocyclic Ligands. Dalton Trans. 2016, 45, $15902-15909$. 
63 Thuéry, P.; Harrowfield, J. Modulation of the Structure and Properties of Uranyl Ion Coordination Polymers Derived from 1,3,5-Benzenetriacetate by Incorporation of $\mathrm{Ag}(\mathrm{I})$ or $\mathrm{Pb}(\mathrm{II})$. Inorg. Chem. 2016, 55, 6799-6816.

64 Thuéry, P.; Harrowfield, J. Tetrahydrofurantetracarboxylic Acid: An Isomerizable Framework-Forming Ligand in Homo- and Heterometallic Complexes with $\mathrm{UO}_{2}{ }^{2+}, \mathrm{Ag}^{+}$and $\mathrm{Pb}^{2+}$. Cryst. Growth Des. 2016, 16, 7083-7093.

65 Thuéry, P.; Harrowfield, J. $\mathrm{Ag}^{\mathrm{I}}$ and $\mathrm{Pb}^{\mathrm{II}}$ as Additional Assembling Cations in Uranyl Coordination Polymers and Frameworks. Cryst. Growth Des. 2017, 17, 2116-2130.

66 Thuéry, P.; Atoini, Y.; Harrowfield, J. 1,2-, 1,3-, and 1,4-Phenylenediacetate Complexes of the Uranyl Ion with Additional Metal Cations and/or Ancillary $N$-Donor Ligands: Confronting Ligand Geometrical Proclivities. Cryst. Growth Des. 2019, 19, 6611-6626.

67 Shibukawa, M.; Shimasaki, T.; Saito, S.; Yarita, T. Superheated Water Ion-Exchange Chromatography: an Experimental Approach for Interpretation of Separation Selectivity in IonExchange Processes. Anal. Chem. 2009, 81, 8025-8032. 


\section{Cavity Formation in Uranyl Ion Complexes with Kemp's Tricarboxylate: Grooved Diperiodic Nets and Polynuclear Cages}

Pierre Thuéry and Jack Harrowfield

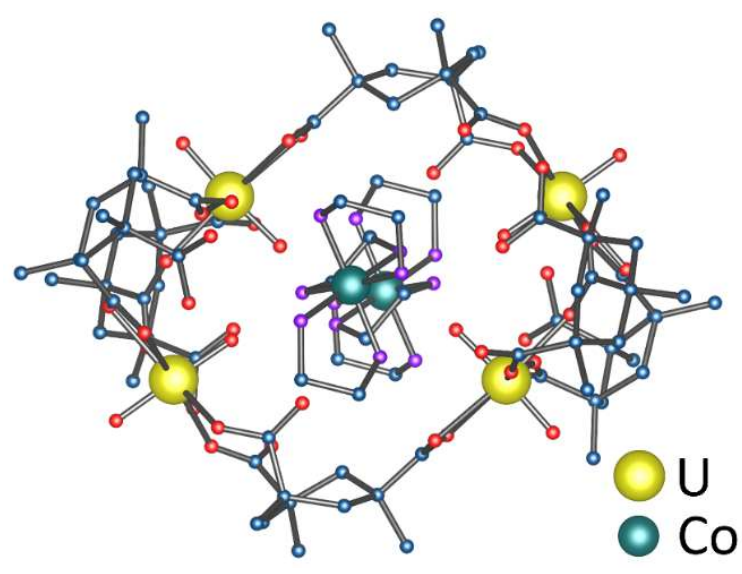

With the two possible chair and boat conformations and equatorial or axial positioning of the coordinating groups, Kemp's acid anions give uranyl ion complexes of various periodicity and geometry. Diperiodic honeycomb networks presenting different degrees of corrugation are the most common, but polynuclear closed species with metallacyclic or cage shapes are also obtained, depending on the counterions used. 